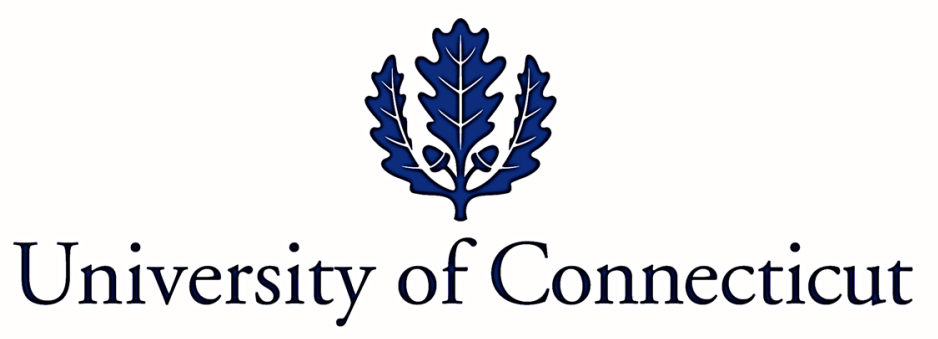

Department of Economics Working Paper Series

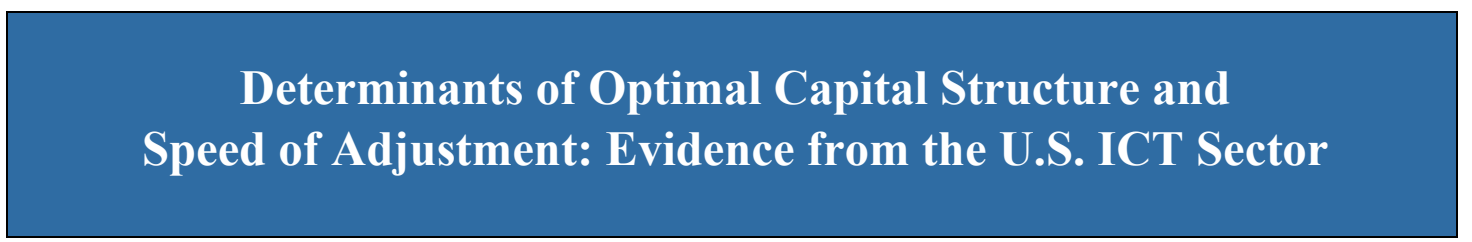

by

Giorgio Canarella

University of Nevada - Las Vegas

Stephen M. Miller

University of Nevada - Las Vegas

Working Paper 2019-06

March 2019

365 Fairfield Way, Unit 1063

Storrs, CT 06269-1063

Phone: (860) 486-3022

Fax: (860) 486-4463

http://www.econ.uconn.edu/

This working paper is indexed in RePEc, http://repec.org 


\title{
Determinants of optimal capital structure and speed of adjustment: Evidence from the U.S. ICT sector
}

\author{
Giorgio Canarella ${ }^{a}$ \\ giorgio.canarella@unlv.edu \\ and \\ Stephen M. Miller ${ }^{\mathrm{a}, *}$ \\ stephen.miller@unlv.edu
}

\begin{abstract}
We employ a dynamic adjustment model (Flannery and Rangan, 2006) to investigate the determinants of capital structure and speed of adjustment (Drobetz and Wanzenried, 2006) in a panel of 85 U.S. ICT firms over the years 1990 to 2013. We estimate the capital structure using a wide range of factors commonly used in the empirical literature (growth and investment opportunities, profitability, firm size, default risk, and industry median capital structure). We expand on this literature to include two additional determinants: asset turnover, an inverse measure of firm agency costs (Morellec, et al., 2012; Ang, Cole, and Lin, 2000), and R\&D activity (Aghion, et al., 2004). We find that the speed of adjustment increases with firm size, growth opportunities, and distance from the target capital structure, and decreases with default risk and agency costs. We also find that R\&D expenditures and agency costs cause firms to maintain lower levels of debt. We employ four recently developed estimators in dynamic panel-data econometrics: the double-censored fractional estimator (Elsas and Florysiak, 2011), the bias-corrected least-squares dummy-variable estimator (Bruno, 2005), the iterative bootstrap-based bias correction for the fixed-effects estimator (Everaert and Pozzi, 2007), and the fixed-effects quasi-maximum-likelihood estimator (Kripfganz, 2016; Hsiao, et al., 2002). In addition, our panel-data regression results show that in the ICT sector, the leverage ratio exhibits high persistence. Moreover, it positively relates to growth and investment opportunities, firm size, capital investment, and industry median capital structure, and negatively relates to profitability and default risk.
\end{abstract}

Keywords: $\quad$ ICT industry; agency costs; optimal capital structure, dynamic modeling

JEL classification: $\quad$ G21; G28; G32; G34

${ }^{a}$ Department of Economics, Lee Business School, University of Nevada, Las Vegas; Las Vegas, Nevada

* Corresponding author 


\section{Introduction}

The information and communication technology (ICT) sector represents an important dynamic component of the U.S. economy. ${ }^{1}$ Several categories of firms operate in the ICT sector, including telecommunications, semiconductors, electronic manufacturing, and computer software and hardware. $^{2}$ In this paper, we provide new evidence on the financial decisions of ICT firms in the United States and investigate the determinants of their capital structure as well as the speed of adjustment (SOA) of that capital structure, using a sample of ICT firms over the period 1990-2013. We investigate both the full sample, which includes both the manufacturing and service sectors, and the manufacturing sector alone.

ICT firms combine intensive R\&D investment ${ }^{3}$ and enormous growth opportunities, and although subject to the same market forces as other firms, exhibit peculiar characteristics that affect their financial choices and their capital structure. First, ICT firms suffer from high levels of informational asymmetries, resulting in sizable adverse selection and moral hazard problems. Adverse selection arises when outside investors cannot easily discriminate between successful and unsuccessful investment projects, and moral hazard arises when borrowers experience the strong incentive to risk investors' money and pursue high-risk projects. The insiders of the ICT firm may know more about the possibility of the firm's success than outside investors. The ICT firm may face,

\footnotetext{
${ }^{1}$ The link between productivity and the ICT industry has been studied extensively at the macro level (e.g., Jorgenson and Stiroh, 1999; Jorgenson and Timmer, 2011), as well as at the micro level (e.g. Bertschek, 2012; Cardona, et al. 2013).

${ }^{2}$ The existing literature defines firms, in general, as a collection of assets in place and growth opportunities (Myers, 1977; Myers and Majluf, 1984; Rajan and Zingales, 1995).

${ }^{3}$ ICT firms account for a large share of R\&D expenditures in the United States. According to the Business R\&D and Innovation Survey ${ }^{3}$ (BRDIS), the ICT sector performed 41 percent of the $\$ 323$ billion of R\&D performed by firms in the United States in 2013. This was 2.5 times larger than the pharmaceutical manufacturing industry, the single largest industry in terms of R\&D expenditures in the United States (http://www.nsf.gov/statistics/2016/nsf16313/). In 2016, the ICT sector performed an even higher 43 percent of the $\$ 375$ billion United States firms spent on R\&D (https://www.nsf.gov/statistics/2018/nsf18312/). For details, see National Science Foundation, National Center for Science and Engineering Statistics, and U.S. Census Bureau. Business R\&D and Innovation Survey, 2013 and 2016.
} 
therefore, significant financial constraints. Adverse selection emerges as a severe problem in ICT debt markets, because the ICT firms' investment projects associate with high levels of uncertainty. The specific design on private equity markets assists in overcoming the information asymmetries inherent in ICT capital markets. Informational asymmetries are much less of a problem for venture capitalists than for banks. Second, ICT firms depend heavily on knowledge capital, which, unlike tangible assets, does not provide collateral (Brierley, 2001). As a result, firms with large R\&D expenditures hold less debt. Third, ICT firms must develop rapidly, since the ageing of technology make them increasingly vulnerable to obsolescence. Fourth, ICT firms face low tax benefits of debt. In the early stage of development, ICT firms may not benefit from debt tax benefits (debt-tax shields) because they experience low or negative earnings. They do benefit, however, from significant nondebt tax shields, such as $R \& D$ expenditures. $R \& D$ activity generally requires large amounts of capital. ICT firms, however, may have trouble accessing debt markets because R\&D investment is risky and cannot serve as good collateral (Simerly and Li, 2000; Vicente-Lorente, 2001). Thus, although ICT firms grew in importance for the economy and provide a major source of innovation and growth, obtaining funding for ICT firms remains particularly problematic.

Vast and diverse empirical research exists in this field, but only a few papers have recently addressed some aspects of the financial structure of ICT firms. Castro, et al. (2015) analyze the effect of a firm's life-cycle stages on capital structure in tech versus non-tech firms using a sample of firms from Europe and provide evidence that tech firms use less debt than non-tech firms during all lifecycle stages. Hogan and Hutson (2005) using a sample of Irish software firms report evidence that internal funds provide the most important source of funding in new technology-based firms and that equity financing, rather than debt financing, provides the main source of external finance. Hyytinen and Pajarinen (2005) using data from Finland find evidence that the leverage of ICT firms is more 
conservative than that of non-ICT firms and that the equity dependence of ICT firms directly links to the ICT firms' R\&D investments. Aghion, et al. (2004) using U.K. data determine that firms that report $R \& D$ more likely raise funds by issuing shares than firms that report no R\&D. Moreover, this probability increases with $R \& D$ intensity. Firms that report R\&D hold lower debt compared to those that do not, and debt tends to fall as R\&D intensity rises. Bruinshoofd and de Haan (2005) analyze the financial behavior of a sample of North-American and Western-European firms during 19912002 and document that ICT firms are indeed what they are always said to be: relatively information intensive and risky firms.

Do ICT firms make different financial choices than non-ICT firms? Are they "really different" (Bruinshoofd and de Haan, 2005)?

Capital structure holds an important place in corporate finance studies for more than a half century, since the seminal work of Modigliani and Miller (1958). They argued, under several restrictive assumptions, that capital structure does not affect the value of the firm and the cost of capital. Theoretical developments on this issue place much emphasis on relaxing the assumptions originally made by Modigliani and Miller (1958), in particular accounting for bankruptcy costs (Titman, 1984), agency costs (Jensen and Meckling, 1976), and information asymmetries (Myers 1984; Myers and Majluf, 1984), while the empirical developments improved immensely from the new estimation methods in the field of panel-data econometrics. Still, as Myers (2001) points out, we do not have an undisputed view that explains the choice between debt and equity. Two influential theories, however, dominate the capital structure literature: the trade-off and pecking order theories.

The trade-off theory grew out of the debate on the Modigliani and Miller (1958) irrelevance propositions. According to the trade-off theory, the capital structure of a firm reflects a trade-off between the benefits of debt (tax shield, the disciplinary role of debt, and the fact that debt suffers 
less informational costs than outside equity) and the costs of debt (bankruptcy costs, the costs of financial distress, and the agency costs between shareholders and bondholders). See, for example, Bradley et al. (1984), Leland (1994), Leary and Roberts (2005), and Strebulaev (2007), among many others. From the original static version where firms always stay in equilibrium at the optimal capital structure, the trade-off theory has evolved into the current dynamic version, which considers the costs of adjustment to the optimal capital structure. Evidence in favor of a dynamic capital structure is overwhelming. See, among the recent contributions, De Miguel and Pindado (2001), Flannery and Rangan (2006), Drobetz and Wanzenried (2006), López-Gracia and Sogorb-Mira (2008), Huang and Ritter (2009), Elsas and Florysiak (2011), Hovakimian and Li (2012), Faulkender, et al. (2012), and González and González (2012).

The pecking-order theory, as described by Myers (1984) and Myers and Majluf (1984), on the other hand, postulates that the informational asymmetries that exist between insiders of the firm and outsiders (the financial markets) are central to capital structure decisions, leading managers to prefer sources of financing associated with the least informational asymmetry. Consequently, firms prefer internal financing to external financing, and risky debt over equity. Harris and Raviv (1991) and Baker and Martin (2011) provide a comprehensive review of the two theories. ${ }^{4}$

The current empirical literature has identified several firm characteristics that correlate with firm leverage. For example, most empirical analyses find a negative relationship between income variability and leverage (Harris and Raviv, 1991; Kim, et al. (2006); Frank and Goyal, 2009), a

\footnotetext{
${ }^{4}$ A vast amount of research has attempted to solve what Myers (1984) has named the "capital structure puzzle." That is, do firms that differ across industries and countries follow the trade-off or pecking-order theories? Important contributions include Rajan and Zingales (1995), Shyam-Sunder and Myers (1999), Fama and French (2002), Flannery and Rangan (2006), Faulkender and Petersen (2006), Lemmon, et al. (2008), and Frank and Goyal (2009), among many others. From the empirical perspective, it proves difficult to find evidence that favors one theory over the other (Rajan and Zingales, 1995; Graham and Harvey, 2001). Fama and French (2002) provide evidence that elements of each theory finds some empirical support, leading Barclay and Smith (2005) to argue that the two theories are complementary, rather than alternative, hypotheses. See also Mukherjee and Mahakud. (2012).
} 
negative correlation between firm's growth opportunity and leverage (Titman and Wessels, 1988; Rajan and Zingales, 1995; Heshmati, 2002), a positive correlation between leverage and tangibility (Myers and Majluf, 1984; Titman and Wessels, 1988; Heshmati, 2002; Frank and Goyal, 2009), a positive correlation between firm size and its leverage (Jensen and Meckling, 1976; Titman and Wessels, 1988; Rajan and Zingales, 1995), a negative correlation between profitability and leverage (Myers and Majluf, 1984; Rajan and Zingales, 1995; Banerjee, et al., 2004), a negative correlation between the non-debt tax shield and leverage (Heshmati, 2002), a negative correlation of a firm's uniqueness and debt financing (Titman and Wessels, 1988), a negative correlation between R\&D and leverage (Singh and Faircloth, 2005; Aghion, et al., 2004; Chang and Song, 2014), and a positive correlation between firm leverage and industry median leverage (Frank and Goyal, 2009).

We generally follow these lines of work but differ from the existing literature as we emphasize the role of agency costs as a determinant of capital structure and its SOA. The financial literature documents that managers do not make capital structure decisions with the goal of maximizing shareholders' wealth (Jensen, 1986; Jensen and Meckling, 1976). The interests of managers, shareholders, and debt holders do not typically overlap. The firm's capital structure affects the relationships between the three parties, and managers' decisions affect the investors' returns.

Managers may follow their own interests and pursue investment such as empire building that reduces the value of the firm (Jensen, 1986; Jensen and Meckling, 1976). This problem relates to the principal-agent problem. Such managerial decisions fully affect shareholders because they can only claim the residual after the firm pays all other obligations. As a result, shareholders face substantial risk. 
Managers' decisions on capital structure also affect debt holders. Capital structure affects credit risk and, consequently, the valuation of debt. Besides the conflict between managers and shareholders, conflict also exists between shareholders and debt holders (Jensen and Meckling, 1976; Myers, 1977; Morellec, et al., 2012), and shareholders may influence decisions that harm debt holders.

Thus, two well-known types of agency costs exist within firms: agency costs of shareholders, resulting from overinvestment, and rooted in the separation of ownership and control, and the principal-agent problem, and agency costs of debt holders, resulting from underinvestment and asset substitution or risk shifting. Asset substitution and underinvestment, which are detrimental to debt holders, more likely occur in R\&D intensive industries such as the ICT sector than in traditional industries (Bah and Dumontier, 2001). For asset substitution, the agency problem arises when shareholders engage in high-risk investment and expropriate value from the debt holders (Jensen and Meckling, 1976; Garvey and Mawani, 2007), while for underinvestment, the agency problem arises when shareholders bypass relatively safe, positive net present value (NPV) opportunities at the expense of debt holders (Myers, 1977).

From this perspective, debt holders bear the highest risk. Since these risks from underinvestment and asset substitution hold debt owner hostage, they require a higher risk premium, which, in turn, increases the cost of debt and results in lower debt levels. According to Morellec, et al. (2012), while the capital structure literature extensively emphasizes the effect of agency costs on capital structure, it is silent on the empirical magnitude of this effect. Morellec, et al. (2012) are the first to investigate explicitly the effects of agency costs on firm financing decisions. They estimate the agency costs of managerial entrenchment in a contingent claims model of firm financing and find an intriguing implication: the greater the severity of agency conflicts, the lower leverage, and 
the slower the SOA. Liao, et al. (2015) and Chang, et al. (2014) include corporate governance as an additional determinant of leverage and effectively confirm the finding of Morellec, et al. (2012).

While these papers constitute important steps towards more realistic tests of capital structure, they follow the traditional approach of relating agency costs to corporate governance. In our paper, we take a different approach. We follow Ang, et al. (2000) and employ asset turnover as a measure of firm efficiency and as an inverse measure of agency costs. We take asset turnover observed in the data as given. We remain silent on whether the observed asset turnover is optimal from the viewpoint of shareholders. Rather, we focus on how the observed asset turnover affects managers' financing decisions. The capital structure research documents various determinants of leverage adjustment speed. For example, the SOA towards the target depends on the distance between observed leverage and its target level, firm size, and growth opportunities (Drobertz and Wanzenried, 2006; Liu, 2001; Aybar-Arias, et al., 2012). Our results also confirm the finding of Morellec, et al. (2012).

Recent research began to investigate two important issues relevant to the analysis of SOA. First, how can we generate consistent estimates of the SOA in short, dynamic unbalanced panels with unobserved firm fixed effects. Evidence exists that estimates of SOA are highly sensitive to the econometric methods and procedures employed in the analysis. See, for example, Huang and Ritter (2009), Iliev and Welch (2010), Flannery and Hankins (2013), Dang, et al. (2012). The empirical literature provides several examples of estimators of SOA, including the pooled ordinary least squares (OLS) (Kayhan and Titman, 2007), the fixed-effects estimator (OLS FE) (Flannery and Rangan, 2006), the Blundell-Bond system Generalized Method of Moments (SYS-GMM) estimator (Lemmon, et al., 2008), the bias-corrected least-squares dummy variable (LSDVC) (Moyo, 2016), the long-difference instrument-variable estimator (LD GMM) (Huang and Ritter, 2009), and the doublecensored dynamic panel fractional estimator (DPF) (Elsas and Florysiak, 2011). Except for the DPF 
estimator, however, these estimators fail to address the mechanical mean reversion issue of leverage, and potentially produce exaggerated estimates of SOA. The issue, as discussed in Chen and Zhao (2007), Chang and Dasgupta (2009) Iliev and Welch (2010), and Elsas and Florysiak (2011), results from the fractional nature of the leverage ratio (i.e., the leverage ratio falls between zero and one).

Second, what determines SOA and do different firms take heterogeneous paths towards their target leverage. Existing studies use a partial-adjustment model of leverage and report estimates of SOA that is the same for all firms and all years. Nevertheless, even under this homogeneity assumption, the literature on the size of the SOA is still discordant. Ozkan (2001) estimates the SOA for U.K. firms as 41 percent using a sample of 390 U.K. firms employing the Arellano and Bond (1991) difference GMM estimator. Fama and French (2002) document a SOA of 10 percent for U.S. firms. More recently, Flannery and Rangan (2006) report a SOA of about 34 percent for U.S. firms, employing fixed-effects and instrumental-variables (IV) estimators. Lemmon, et al., (2008) estimate a SOA of 25 percent using the Blundell and Bond (2000) GMM estimator, Huang and Ritter (2009) estimate a SOA of 23.2 percent for U.S. firm, employing the long difference estimator of Hahn, et al. (2007). Elsas and Florysiak (2011) report a SOA of 26.3 percent, using an unbalanced panel of U.S. firms and applying the DPF estimator. The DPF estimator explicitly addresses the concerns raised by Chang and Dasgupta (2009) and Iliev and Welch (2010) over the fractional nature of leverage and its latent mean-reversion tendency. Fama and French (2002) report SOA ranging from seven to 18 percent, while Welch (2004) reports SOA as practically zero.

The homogeneity assumption is unrealistic. Firms exhibit different capital structures and face different capital market conditions. This leads to different speeds of adjustment toward their firmspecific target leverage. The dynamic trade-off theory of capital structure suggests that firms experience differences in the costs of adjustments and only adjust their capital structure when the 
costs of adjustment are offset by the benefits of adjustment (Fischer, et al., 1989). This is an empirical issue, but overall the argument suggests that SOA is heterogeneous because firms facing higher costs of adjustment are likely to adjust more slowly than firms facing lower costs. Intuitively, SOA is unlikely the same during the Great Recession and the pre- and post-recession periods.

We deal with these two issues as follows. We employ the DPF estimator (Loudermilk, 2007; Elsas and Florysiak, 2011, 2015) to address the first issue. We examine the robustness of the DPF results applying three additional recently developed estimators: 1) the bias-corrected least-squares dummy-variable estimator (Bruno, 2005; Flannery and Hankins, 2013); 2) the iterative bootstrapbased bias correction for the fixed-effects estimator (De Vos, et al., 2015; Everaert and Pozzi, 2007); and, 3) the fixed-effects quasi-maximum-likelihood estimator (Kripfganz, 2016; Hsiao, et al., 2002). These estimators are attractive alternatives to the widely used GMM estimators (Arellano and Bond, 1991; Blundel and Bond, 2000) and have the potential of greater efficiency gains and better finite-sample performance. For comparison, we also present the results of the two-step SYS-GMM (Blundel and Bond, 2000). We treat the estimates obtained by the DPF estimator as our main results. The DPF results, however, do not differ qualitatively much from the three additional econometric methods. We deal with the second issue by removing the traditional assumption that SOA is the same for all firms and all years and developing a model where SOA is itself a function of agency costs and other firm characteristics.

We organize the remainder of the paper as follows. Section 2 develops a capital structure model based on partial adjustment under the heterogeneity assumption of SOA. Section 3 discusses the different factors that affect capital structure and the SOA. Section 4 examines the empirical methodology and section 5 presents our empirical findings. Section 6 concludes. 


\section{A Generalized Partial Adjustment Model of Capital Structure}

In this section, we describe our model that defines the determinants of target capital structure, incorporates the heterogeneity of the SOA, and specifies the estimation strategy. We assume that firms face transaction costs and only partially adjust their current leverage each period to their target or optimal leverage. In a frictionless world, firms would always achieve their target. Adjustment costs, however, hinder full instantaneous adjustment to the target and firms compare the cost of a suboptimal position to the cost of adjusting. We also assume that the optimal leverage varies across firms and over time as the factors that determine optimal leverage vary over time and across firms. For the same reasons, we also assume that the SOA, the rate at which firm adjust their capital structure from one period to the next, also varies over time and across firms. Typically, the SOA lies between zero and one, with a higher value indicating a more rapid adjustment in line with the prediction of the dynamic trade-off theory.

We follow prior research (Flannery and Rangan, 2006; Oztekin and Flannery, 2012; Faulkender, et al., 2012) and model the adjustment process toward the target leverage using the following partial adjustment mechanism:

$$
L_{i t}-L_{i t-1}=\delta+\lambda\left(L_{i t}^{*}-L_{i t-1}\right)+\varepsilon_{i t},
$$

where $L_{i t}^{*}$ is the target (or optimal) leverage ratio for firm $i$ at time $t, L_{i t}$ and $L_{i t-1}$ represent the actual (observed) leverage ratio for firm $i$ at time $t$ and $t-1$, and $\lambda$ represents the SOA to the target leverage ratio (De Miguel and Pindando, 2001). The adjustment costs inversely relate to $\lambda$ and we can represent them as $(1-\lambda)$ (López-Gracia and Sogorb-Mira 2008). Leverage ratios that deviate from $L_{i t}^{*}$ are sub-optimal. Four cases can exist. One, a value of $\lambda<1$ implies the presence of adjustment costs and predicts the persistence of suboptimal leverage ratios. This is consistent with the stability condition $|\lambda|<1$, which implies that $L_{i t} \rightarrow L_{i t}^{*}$ as $t \rightarrow \infty$. Two, a value of $\lambda=1$ indicates that the 
firm fully adjusts for any deviation away from its target leverage immediately (i.e., the firm leverage ratio always achieves the target, $L_{i t}=L_{i t}^{*}$ ). Three, a value of $\lambda=0$ implies that adjustment costs are extremely high, and the firm never adjusts to its target leverage (i.e., leverage is "sticky" and $\left.L_{i t}=L_{i t-1}\right)$. Finally, if $\lambda>1$, then a firm adjusts more than is necessary, but is still not at its target level (Lö̈f, 2003).

We specify the target leverage ratio $L_{i t}^{*}$ for firm $i$ at time $t$ as a linear function of a set of firm characteristics $\mathbf{X}_{j i t}(j=1, \ldots, L)$ that the capital structure literature typically considers:

$$
L_{i j t}^{*}=\boldsymbol{\theta}^{\prime} \mathbf{X}_{j i t},
$$

where $\mathbf{X}_{j i t}$ denotes the explanatory variables of target leverage documented in the literature (De Miguel and Pindado 2001; Flannery and Rangan 2006; López-Gracia and Sogorb-Mira 2008) and $\boldsymbol{\theta}^{\prime}$ is a vector of the corresponding coefficients. We follow Elsas and Florysiak (2015) and Flannery and Rangan (2006) and employ the one-stage approach in estimating SOA. This involves substituting Eq. (2) into Eq. (1) to yield the following dynamic panel data model:

$$
L_{i t}=\delta+(1-\lambda) L_{i t-1}+\gamma^{\prime} \mathbf{X}_{i j t}+\varepsilon_{i t},
$$

where $\varepsilon_{i t}=\varphi_{i}+\varphi_{t}+e_{i t}, \varphi_{i}$ is a firm-specific effect, $\varphi_{t}$ is a time-specific effect, and $e_{i t}$ is a stochastic error term, independent and identically distributed (iid) with constant variance. The firm-specific effect $\varphi_{i}$ controls for unobservable heterogeneity of the firms, which differs across firms and constant over time, while the time specific effect $\varphi_{t}$ controls for macroeconomic factors that are identical for all firms and vary over time.

In Eq. (3), the SOA is homogeneous (i.e., constant across firms and through time). According to our main hypothesis, the SOA of leverage in Eq. (3) is determined by the severity of agency costs 
and other firm characteristics, including firm size, firm growth, distance of the actual leverage from the target leverage, and the risk of financial distress. We re-write Eq. (3) to consider the heterogeneity of SOA as follows

$$
L_{i t}=\delta+\left(1-\lambda_{i t}\right) L_{i t-1}+\gamma^{\prime} \mathbf{X}_{i j t}+\varepsilon_{i t},
$$

and model $\lambda_{i t}$ as

$$
\lambda_{i t}=\beta_{0}+\boldsymbol{\beta}^{\prime} \mathbf{Z}_{i j t},
$$

where $\mathbf{Z}_{i j t}$ is a vector of firm characteristics that affect the SOA of leverage and $\boldsymbol{\beta}^{\prime}$ is the corresponding vector of coefficients. Substituting Eq. (5) into Eq. (4) and rearranging terms yields the following generalized dynamic panel data model of leverage:

$$
\begin{aligned}
& L_{i t}=\delta+\left(1-\left(\beta_{0}+\boldsymbol{\beta}^{\prime} \mathbf{Z}_{i j t}\right) L_{i t-1}+\gamma^{\prime} \mathbf{X}_{i j t}+\varepsilon_{i t} .\right. \text { That is, } \\
& L_{i t}=\delta+\xi^{\prime} \mathbf{Z}_{i j t} L_{i t-1}+\left(1-\beta_{0}\right) L_{i t-1}+\gamma^{\prime} \mathbf{X}_{i j t}+\varepsilon_{i t},
\end{aligned}
$$

where $\xi^{\prime}=-\boldsymbol{\beta}^{\prime}$. In Eq. (6), $\beta_{0}$ is the estimate of base SOA, while the coefficient vector $\gamma^{\prime}$ relates the impact of the firm characteristics and agency costs $\mathbf{X}_{i j t}$ on leverage, and the coefficient vector $\xi^{\prime}$ on the interaction terms $\mathbf{Z}_{i j t} L_{i t-1}$ captures the effects the effect of firm characteristics and agency costs on SOA.

\section{Econometric Methodology}

Leverage ratios are fractional in nature. They are bounded between 0 and 1 . This property renders the difference GMM, SYS-GMM biased in the context of unbalanced dynamic panel data with a fractional dependent variable. These estimators ignore the fractional nature of the dependent variable. Elsas and Florysiak $(2011,2015)$ propose a new estimator that can yield unbiased adjustment speed estimates. The estimator is unbiased and consistent in the context of unbalanced dynamic panel data with a fractional dependent variable (i.e., DPF). The DPF estimator is a double 
censored Tobit estimator that allows for two corner solution outcomes, with a minimum of 0 and a maximum of 1 . The DPF estimator is a ML estimator, which builds on the work of Loudermilk (2007) to allow for unbalanced panel data. To take the fractional nature of $L_{i t}$ into account, the DPF estimator employs a latent variable specification. The latent variable is given by

$$
\hat{L}_{i t}=\sum_{j=1}^{J} \gamma_{j} X_{j i t}+\rho L_{i t-1}+c_{i}+\mu_{i t}
$$

where $c_{i}$ denotes the time-invariant unobservable firm fixed effects and $\mu_{i t}$ is a normally distributed error with mean 0 and variance $\sigma^{2}$. The observable double censored leverage ratio $L_{i t}$ is then given by

$$
L_{i t}=0 \mid \begin{array}{ll}
0 & \text { if } \hat{L}_{i t} \leq 0 \\
\hat{L}_{i t} & \text { if } 0 \leq \hat{L}_{i t} \leq 1 \\
1 & \text { if } \hat{L}_{i t} \geq 1
\end{array}
$$

Following Wooldridge (2005), we specify the conditional distribution of the fixed effects for Eq. (7) given (8) as follows:

$$
c_{i}=\eta_{0}+\eta_{1} L_{j i, 0}+\overline{\mathbf{Z}}_{i} \boldsymbol{\eta}_{2}+a_{i}
$$

where the error term $a_{i}$ is $N\left(0, \sigma_{a}^{2}\right)$ and $\overline{\mathbf{Z}}_{i}$ is the vector of time averages of the $Z_{i t}$ variables. See Wooldridge (2010) for a discussion of the advantages of this modelling strategy. In essence, the DPF estimation is a combination of the Tobit model (Tobin, 1958), i.e., Eq. (7) given (8), and the correlated random-effect model, i.e., Eq. (9), with two additional regressors, the initial value of the dependent variable, $L_{j i, 0}$, and the time averages of the vector $\overline{\mathbf{Z}}_{i}$. 


\section{Determinants of Capital Structure and SOA}

\subsection{Determinants of Capital Structure}

The literature has identified several firm characteristics that help to explain firms' capital structure (Frank and Goyal, 2009; Rajan and Zingales, 1995). We select the following variables for our empirical investigation: firm size (SIZE), default risk (RISK), profitability (ROA), growth opportunities (GROWTH), research and development expenditures (R\&D), asset turnover (TURNOVER) and industry median capital structure (MEDIAN), which generally influence capital structure (see, among others, Rajan and Zingales, 1995; Drobetz and Wanzenried, 2006; Getzmann, et al., 2014). Our measure of research and development expenditures (R\&D) provides a proxy for asymmetric information while the inverse of asset turnover (TURNOVER) provides a measure of agency costs.

As the dependent variable in our model, we use the ratio of total debt (the sum of short- and long-term debt) to total assets in book value to measure leverage, since managers focus on book values when designing financial structure (Mackay and Phillips, 2005). Myers (1977) argues that book leverage proves most useful because market volatility and expectations do not distort it. Moreover, the expected cost of financial distress in the event of bankruptcy represents the cost of borrowing, and the book value of debt rather than market value provides the relevant measure of the debt liability. We follow Flannery and Rangan (2006) and Flannery and Hankins (2013) and use the natural logarithm of total assets to measure firm size. The trade-off theory suggests a positive relationship between firm size and leverage, based on the risk-of-default argument. Large firms can borrow more than small firms because they are more diversified and are less exposed to default risk and financial distress. The pecking-order theory also identify a positive relationship between firm size and leverage, based on the information asymmetry argument. Large firms provide more 
information to financial markets and, thus, are more likely to have access to credit markets. In contrast, Rajan and Zingales (1995), Chang and Dasgupta (2009), and Cortez and Susanto (2012) find that leverage decreases with firm size.

The pecking-order theory suggests a negative association between profitability and leverage. That is, more profitable firms likely exhibit less leveraged than less profitable firms because they hold more internal funds and depend less on external financing. Harris and Raviv (1991), ShyamSunder and Myers (1999), Chang and Dasgupta (2009), Frank and Goyal (2009), and Rajan and Zingales (1995), among others, provide significant evidence of the inverse relation between profitability and leverage. Myers and Majluf (1984) argue that this inverse relationship offers the most compelling evidence against the trade-off theory. On the other hand, the trade-off theory assumes a positive relation between profitability and leverage. Profitable firms experience higher taxable earnings and so should benefit more from debt-tax shields. Profitability also sends signals to the capital markets regarding the health of the firm and, thus, reduces informational asymmetries that are the major obstacle to the financing of ICT firms.

Like profitability, firm growth is a controversial factor in determining capital structure and financial leverage. The trade-off theory predicts that firms with high growth potential prefer less debt financing, because these firms experience a higher cost of financial distress. On the other hand, the pecking-order theory predicts a positive relationship between firm growth and leverage, since growing firms need more debt to finance their investments, holding profits constant (e.g. Frank and Goyal, 2009). We measure growth opportunities by growth in assets, as in Fama and French (2002), and expect a positive coefficient.

As mentioned earlier, $R \& D$ investments are risky, exhibit pronounced asymmetric information problems, and do not generate tangible assets that are commonly used as collateral. As 
a result, firms with high $\mathrm{R} \& \mathrm{D}$ investments cannot borrow even though they would if debt was available. This thinking suggests an inverse relationship between R\&D investment and firm leverage. We measure R\&D investment by expenditures in $R \& D$ divided by total sales.

Default risk, as measured by the volatility of earnings, associates with the probability of financial distress. Firms with higher default risk are expected to exhibit lower levels of leverage. This outcome is predicted by both the trade-off and pecking-order theories.

Following Ang, et al. (2000), asset turnover provides an inverse measure (proxy) of agency costs. The agency cost of debt reflects the risks of underinvestment and asset substitution. Since debt holders sustain these risks, debt holders require a higher risk premium, which, in turn, increases the cost of debt and results in lower debt levels. Thus, the agency theory perspective suggests an inverse relation between agency costs and leverage, resulting from a positive relation between asset turnover and leverage. ${ }^{5}$ We measure default risk by the squared difference between the return on assets and the average (by year) return on assets

In addition to firm characteristics, we follow Frank and Goyal (2009) and include the median industry leverage as an additional determinant of capital structure. Commonly, researchers argue that industry leverage acts as a benchmark, and managers consider the industry leverage when choosing their own debt structure. The current literature (Frank and Goyal, 2009; Degryse, et al., 2012) suggests a positive association between median industry leverage and the firm's leverage. We measure the median industry leverage as a median of leverage by ICT industry and by year.

\footnotetext{
${ }^{5}$ Berger and Bonaccorsi di Patti (2006), who analyze the effects of efficiency on capital structure based on two competing hypotheses, suggest an alternative view. Under the "efficiency-risk hypothesis," more efficient firms tend to choose higher leverage ratios because they are less likely to fail (i.e., higher efficiency reduces the expected costs of bankruptcy, liquidation, and financial distress). Thus, this hypothesis predicts that efficiency exerts a positive effect on leverage (i.e., efficient firms will substitute debt to equity). On the other hand, under the "franchise-value hypothesis," more-efficient firms may choose lower leverage ratios because they want to protect the economic rents derived from higher efficiency from the threat of liquidation.
} 


\subsection{Determinants of the SOA}

We hypothesize that the SOA toward the target capital structure, $\lambda_{i t}$ (Eq. 5), depends on five firmspecific characteristics. Four of these also affect the target leverage ratio (GROWTH, SIZE, TURNOVER, and R\&D). The fifth variable (DISTANCE) measures the distance between the current leverage ratio and the target leverage ratio as follows:

$$
\operatorname{DISTANCE}_{i t}=\left|L_{i t}^{*}-L_{i t}\right|,
$$

where $L_{i t}^{*}$ is the fitted value from a fixed-effect regression explaining the actual leverage ratio in period $t, L_{i t}$, with the capital-structure determinants GROWTH, ROA, SIZE, TURNOVER, R\&D, RISK, and MEDIAN. Drobetz and Wanzenreid (2006) argue that if fixed costs (such as legal and investment bank fees) are a major portion of the total cost of changing the capital structure, firms with sub-optimal leverage will change their capital structure only if they are a sufficient distance from the target capital structure. Accordingly, we hypothesize that the likelihood of adjustment depends positively on the absolute difference between target and observed leverage. Growing firms may find it easier to change their capital structure as more alternatives may exist. Thus, we expect a positive relationship between GROWTH and SOA. Large firms experience relatively smaller fixed costs than small firms and, thus, large firms may be able to adjust more quickly than small firms. Therefore, we expect a positive relation between SIZE and SOA. Firms with severe agency costs may also find it difficult to adjust and rebalance their capital structure. Consequently, we expect a negative (positive) relationship between agency costs (TURNOVER) and SOA. Finally, we expect a negative relationship between RISK and SOA, as firms with a higher default risk may experience difficulties refinancing their debt. 


\section{Data and Summary Statistics}

We use firm-level annual data from 85 U.S. ICT firms that operated during the whole period 19902013. We obtain our sample from the Standard and Poor's Compustat Annual North America database (Economic Sector Code: 8000). We do not isolate outliers, such as firms with high growth rates, as this procedure associates with the risk of excluding firms with truly high growth rates, and do not impose any restrictions on a minimum amount of net sales or total assets. The data constitute a mildly unbalanced panel, and comprise seven sectors of the ICT industry: 1) Telecommunication Equipment (8030); 2) System Software (8140) and Application Software (8130); 3) Semiconductors (8230) and Semiconductor Equipment (8220); 4) Computer Hardware (8050) and Computer Storage and Peripherals (8052); 5) Electronic Manufacturing Services (8200) and Consulting Services (8120); 6) Electronic Equipment and Instruments (8150); and 7) Technology Distributors (8210), where the Compustat industry sector codes appear in parentheses. ${ }^{6}$ The sample includes, among others, well-known worldwide firms, such as Intel, Oracle, Adobe Systems, Microsoft, IBM, Cisco Systems, Xerox, Texas Instruments, and Hewlett Packard.

Table 1 reports the ICT industry sample distribution. Semiconductors and Semiconductor Equipment, the largest category, comprises 22 percent of the sample. Electronic Equipment and Instruments and Electronic Manufacturing Services and Consulting Services comprise 21 percent and 18 percent of the sample, respectively. The smallest industry category, Technology Distributors, comprises just four percent of the sample.

\footnotetext{
${ }^{6}$ Using the North American Industrial Classification System (NAICS), the ICT industry is defined as the sum of ICT manufacturing (NAICS 334: Computers and Electronic Products, including Computer and Peripheral Equipment, Communication Equipment and Semiconductors), and ICT services (NAICS 5112: Software Publishers; NAICS 517: Telecommunications, including Wired and Wireless Telecommunications; NAICS 518: Data Processing, Hosting, and Related services; NAICS 5415: Computer Systems Designs and Related Services; and NAICS 51: Information), excluding traditional paper publishing.
} 
Table 2 enumerates summary statistics over the entire sample period (1990-2013), the mean, standard deviation, and minimum and maximum values. We compute leverage as the sum of longterm debt (Compustat item no. 9) and short-term debt (Compustat item no. 12) divided by total assets (Compustat item number 6). The minimum and maximum values of the leverage ratio equal zero percent (Computer Hardware and Computer Storage and Peripherals; Electronic Manufacturing Services and IT Consulting Services; and Electronic Equipment and Instruments) and 92.26 percent (Technology Distributors) with an average of 38.05 percent. The natural logarithm of total assets equals firm size. We compute asset turnover as net sales (Compustat item no. 12) divided by total assets (Compustat item no. 6). The minimum and maximum values of the asset turnover ratio equal 1.37 percent (Electronic Equipment and Instruments) and 622.5 percent (Electronic Manufacturing Services and IT Consulting Services) with a mean of 110 percent. We compute R\&D intensity as R\&D expenditure (Compustat item no. 46) divided by net sales (Compustat item no. 12). The minimum and maximum values of $R \& D$ intensity equal zero percent for one or more firms (in all industries except Telecommunication Equipment; and Semiconductors and Semiconductor Equipment) and 277 percent for one firm (Electronic Equipment and Instruments) with an average of 9.3 percent across all firms. The large range of maximum and minimum values for all variables shows that the sample covers both large and small firms. We compute firm growth as the logarithmic first difference of total assets (Compustat item no. 6). The minimum and maximum values of the firm growth equal -105 percent (Electronic Equipment and Instruments) and 172 percent (Telecommunication Equipment) with an average of 9.7 percent. We compute ROA as income before extraordinary items (Compustat item no. 18) divided by total assets (Compustat item no. 6). The minimum and maximum values of ROA equal -154.1 percent (Semiconductors and Semiconductor Equipment) and 53.1 percent (Telecommunication Equipment) with an average of 
4.43 percent. We compute total assets (Compustat item no. 6) as the sum of current assets, net property, plant and equipment, and other noncurrent assets (including intangible assets, deferred items, and investments and advances). The minimum and maximum values of total assets equal \$1.36 million (Electronic Manufacturing Services and IT Consulting Services) and \$114,288 million (Electronic Equipment and Instruments) with an average of $\$ 8,215.872$. Net sales (Compustat item no. 12) equals the amount of sales after the deduction of returns, allowances for damaged or missing goods, and any discounts allowed. The minimum and maximum values of net sales equal $\$ 0.421$ million (Electronic Equipment and Instruments) and \$127,245 million (Computer Hardware and Computer Storage and Peripherals) with a mean of $\$ 7,010,163$ million. $^{7}$

Figures 1-7 in the Appendix highlight the average evolution by year of the relevant variables. The figures highlight the connection with two events of importance to the ICT sector, the dot-com crash of 2000-2002 and the Great Recession of 2007-2008. The average leverage ratio declines from 1990 to 2006, reaching a minimum at the start of the Great Recession. The average ROA severely declines during the dot-com crash and in the aftermath of the Great Recession. The average R\&D peaks in the dot-com crash, while default risk, high during the dot-com crash, is the highest during the Great Recession. Firm growth is the highest before the dot-com crash and the lowest during the Great Recession.

\section{Empirical results}

This section estimates the dynamic adjustment model of leverage using the DPF estimator, and, for robustness, the LSDVC, the BCFE, the QML, and the SYS-GMM estimators. Subsection 6.1 presents the estimates under the assumption of homogeneity of the SOA. Then, subsection 6.2

\footnotetext{
${ }^{7}$ Since we frequently use the ratio of variables, transformation of the variables to constant prices is unnecessary. For variables that we compute in level or non-ratio form, we transform them to constant prices using the GDP deflator $(2012=100)$.
} 
reports the heterogeneous case. In both cases, we control for fixed time effects with yearly dummies, but are not reported (Korajczyk and Levy, 2003; Cook and Tang, 2010).

\subsection{The Homogeneous Case}

Table 3 presents the estimated coefficients of Eq. (3) using Ordinary Least Squares (OLS) and Fixed effects (FE) methods. While the existing literature has established that the OLS and FE estimators are biased in dynamic panels, they do provide the upper and lower bounds for the coefficients of the lagged dependent variable. The positive correlation between the lagged dependent variable and the error term biases upward the OLS results and biases downward the FE estimates, on the contrary. In the FE estimation, demeaning introduces a correlation between the demeaned lagged dependent variable and the demeaned error term when $T$ is small. See Nickell (1981). It follows, therefore, that the true parameter of the lagged dependent variable should fall between 0.729 and 0.838 , thus, implying dynamic stability. For the SOA, this means that the true SOA should lie between 16.2 and 27.1 percent per year for the OLS and FE estimates, respectively. Finally, for half-life, these estimates mean that the firm moves halfway toward its target capital structure from 3.9 to 2.2 years for the OLS and FE estimates, respectively. ${ }^{8}$

Table 4 compares the results on the determinants of firm leverage obtained using the DPF, LSDVC, BCFE, QML, and SYS-GMM methodologies for the restricted case of homogeneity of the SOA. These alternative estimation procedures differ in one important way. While the LSDVC and BCFE approaches first produce biased estimates and subsequently remove the bias based on either analytical bias approximations or with a bootstrap procedure. The DPF, QML, and SYS-GMM approaches avoid the bias in the first place.

\footnotetext{
${ }^{8}$ We compute the half-life statistic as $\ln 0.5 / \ln (1-\lambda)$. See Huang and Ritter (2009).
} 
Table 4 displays in the first column the results of the DPF estimation (Elsas and Florysiak, 2011). As previously mentioned, we treat these estimates as the main results. The next two columns present the results of two estimators that correct the estimation bias either by analytical methods or by bootstrapping. The fixed-effects LSDVC controls for the bias using standard (analytical) methods (Kiviet, 1995; Bruno, 2005), while the BCFE controls for the bias using an iterative bootstrap-based correction procedure (De Vos, et al., 2015; Everaert and Pozzi, 2007). We initialize the bias correction in the LSDVC method using the Blundell and Bond estimator, control for bias correction up to order $O\left(N^{-1} T^{-2}\right)$, and obtain the bootstrapped standard errors using the parametric bootstrap. The BCFE algorithm evaluates the bias of the fixed effects estimator in a numerical way to avoid the use of analytical correction formulas and is, therefore, applicable to models with a potential non-standard error structure. We perform the estimation using the non-parametric bootstrap, allowing for heteroskedasticity and cross-sectional dependence patterns. The last two columns present the fixed-effects QML estimates (Kripfganz, 2016; Hsiao, et al., 2002), and the SYS-GMM estimates (Blundell and Bond, 2000). ${ }^{9}$ The QML approach uses the theoretical work by Bhargava and Sargan (1983) and Hsiao, et al. (2002) and, although asymptotically equivalent to the widely used SYS-GMM estimation, may outperform SYS-GMM when analyzing persistent series in finite samples (Moral-Benito, 2013).

Moreover, the main advantage of QML is that, contrary to GMM methods, it does not use any instruments and, thus, avoids the weak instrument problem described by Roodman (2009). The QML estimator obtains consistent parameter estimates by first differencing the series and then maximizing a transformed likelihood function. Hsiao, et al., (2002) find that this estimator outperforms SYS-GMM in terms of bias and root-mean-square error. The SYS-GMM technique

\footnotetext{
${ }^{9}$ We reduced the instrument set by "collapsing" the instrument set into a smaller dimension matrix (Roodman, 2009).
} 
removes the time-invariant unobservable firm-specific effects by taking the first difference (or the forward orthogonal deviation) of each variable, effectively controlling for the correlation between the regressors and the residuals. In addition, the use of the SYS-GMM method can mitigate the possibility of endogeneity by instrumenting differenced equations with lagged levels of the variables and equations in levels with the lags of the first differences of the variables. The SYSGMM method receives criticism, however, for low robustness against instrument choice. In particular, in large models, weak instruments may produce biased estimates (Roodman, 2009). We confirm the validity of the instruments with the Hansen (1982) statistic. We also apply the ArellanoBond test to examine the presence of second-order autocorrelation in the differenced residuals.

The results conform to expectations and most of the literature. ${ }^{10}$ The estimates of the model exhibit only minor differences across the five methods. Moreover, any differences between the various estimates do not exhibit any statistical significance. This is a very important result. In applied work, the robustness of the estimates obtained with different econometric methods provides a strong indication of $\mathrm{t}$ model reliability.

Lagged leverage exerts a positive and significant effect at the 1-percent level in all five estimation methods. The estimate satisfies the stability condition. This finding confirms that the leverage ratio of ICT firms reverts to the mean and converges over time to a target capital structure as postulated by the dynamic version of the trade-off theory. This also confirms the presence of dynamics in the capital structure decisions of the ICT firms. From the estimated coefficient on lagged leverage, we infer the estimates of the SOA. These estimates range from 19.3\% per annum (LSDVC) to $24.5 \%$ per annum (QML), implying a half-life ranging from 3.2 years (LSDVC) to 2.5 years

\footnotetext{
${ }^{10}$ All the calculations are based on Stata 15 (StataCorp., 2017). In particular, the DPF estimation uses the xtdpf package of Elsas and Florisiak (2011), while the LSDVC and BCFE estimates come from, respectively, the xtlsdvc package of Bruno (2005) and the xtbcfe package of De Vos, et al. (2015). The QML estimation uses the xtdpdqml package of Kripfganz (2016), whereas for the SYS-GMM procedure, we use the package xtabond2 of Roodman (2009).
} 
(QML). These results suggest that ICT firms adjust their leverage policy slowly toward the target ratios. In comparison, Flannery and Rangan (2006) show that the average U.S. firm converges toward its target at a rate of 30 percent per annum. This slow SOA to the target leverage may reflect high adjustment costs. As mentioned earlier, material adverse selection issues exist in the ICT sector, resulting from informational asymmetries, which make adjustment costly.

Firm growth (GROWTH) positively correlates with leverage and all coefficients are significant at the 1-percent level. This result supports the pecking-order theory, because debt typically grows when investment exceeds retained earnings. Profitability (ROA) exhibits a negative and significant relationship at the 1-percent level with leverage, thus supporting the pecking-order hypothesis (i.e., firms with higher profitability hold lower leverage ratios). Firm size (SIZE) is positive and significant at the 1 percent level in all but one of the estimation methods. This finding is consistent with the trade-off theory where firm size proxies for the probability of default. That is, large firms can achieve more diversified than small firms and, thus, are less vulnerable to bankruptcy. R\&D expenditures (R\&D) exerts a significant and negative effect on leverage at the 5percent level in four of the five estimation methods, and at the 1-percent level in the fifth. Importantly, $R \& D$ activities originate greater informational asymmetries than tangible assets, resulting in lower levels of debt. This confirms the findings of Aghion, et al. (2004), Hogan and Hutson (2004), and Chang and Song (2014) that firms with high R\&D investments issue more equity and less debt. Asset turnover (TURNOVER) exerts a significant positive effect on leverage, implying that agency costs produce a negative effect on leverage. This confirms the agency-cost hypothesis that since the debt holders sustain the risks of underinvestment and asset substitution, debt holders require a higher risk premium, which, in turn, increases the cost of debt and results in lower debt levels. The last two factors included in the model are default risk and the industry median 
leverage. Following the trade-off theory, higher default risk (RISK) also significantly lowers leverage at the 1-percennt level in all estimations. Firms with higher earnings volatility use less debt as their higher risk increases expected bankruptcy costs. The highly significant positive estimate on industry median leverage matches the results found by Lemmon, et al. (2008) and Frank and Goyal (2009). The positive effect suggests that managers in the ICT sector use the industry median leverage as a benchmark.

Our results for the U.S. ICT firms fully support the agency cost theory. The negative link between agency costs and leverage is significant and substantive. The findings also partially support both the trade-off and pecking-order theories, although they constitute greater support for the pecking-order theory. The important result consistent with the trade-off theory is the positive and significant coefficient of lagged leverage. On the other hand, the positive and significant coefficient on growth opportunities, the negative and significant coefficient on profitability, R\&D, and default risk support the predictions of the pecking-order theory, while the positive and significant coefficient on firm size proves consistent with both theories. Thus, overall, the DPF, LSDVC, BCFE, QML and SYS-GMM methods provide significant and plausible results in terms of the statistical and economic significance of the coefficients on the relevant explanatory variables of our model.

Recent empirical evidence on capital structure, however, challenges the reliability of these factors, arguing that unobservable firm-specific time-invariant factors explain most of the crosssectional variation in firms' capital structures (Hanousek and Shamshur, 2011; Lemmon, et al., 2008). A direct way to investigate whether unobservable firm-specific effects provide a major explanation of capital structure examines the effect that unobservable firm-specific effects exert on the estimate of the SOA. If unobservable firm-specific effects are a major component of firms' capital structure, little difference should exist between the SOA estimated in Table 4 (that includes firm- 
level determinants and year fixed effects, and account for unobservable firm-specific effects) and the SOA estimated by omitting firm-level determinants and year fixed effects, but accounts for unobservable firm-specific effects. We cannot confirm the hypothesis, as the estimates of the lagged dependent variable lack consistency. The SOA estimates increase in one case to 25.6 percent (DPF) and decrease in the other cases to 9.1 percent (LSDVC), 16.6 percent (BCFE), 17.3 percent (QML), and 3.9 percent (SYS-GMM).

We reinforce the validity of our results by conducting three robustness checks by splitting the sample into three subsamples. First, we estimate the model excluding firms in the software industry, because their accounting treatment of R\&D differs from other ICT firms in that they can capitalize development costs of software according to SFAS No.86 (Chang and Song, 2014). Second, we estimate the model excluding firms in the service sector (i.e., we obtain estimates only of the manufacturing component of the ICT sector). Third, we exclude firms in the semiconductor industry, where $R \& D$ expenditures relative to sales is the highest (15 percent of the sales). We report the estimation results using the five estimation methods in Tables 5-7. We find that the results generally do not change.

\subsection{The Heterogeneous Case}

This subsection presents the results of estimating Eq. (6), which represents our main hypothesis, using the same estimators applied in the previous subsection (i.e., DPF, LSDVC, BCFE, QML, and SYS-GMM). The determinants of the capital structure remain the same (i.e., GROWTH, SIZE, ROA, R\&D, RISK, and MEDIAN). The determinants of the SOA are DISTANCE, TURNOVER, SIZE, GROWTH, and RISK.

Tables 8-12 report the empirical results according to the five different estimators. Each Table

includes two panels. The top panel presents estimates of the determinants of capital structure, and 
the bottom panel reports estimates of the determinants of the SOA. We display estimation results with both one single (columns 1-5) and then multiple (column 6) SOA determinants. This approach addresses both the potential omitted variable problem and the problem of multicollinearity.

The top panel summarizes the effect of firm-specific factors and the industry median leverage on capital structure. The estimates of the determinants of capital structure (top panel) are similar to those presented in Table 4 for the homogeneous case, revealing that the capital structure factors of our model remain appropriate for the time-varying SOA dynamic-adjustment model. As in the homogeneous case, the findings notably support the agency-cost theory. The coefficient estimate on TURNOVER is positive and significant, implying that agency costs exert a negative effect on leverage. The results also support the pecking-order theory: firm size, growth opportunities, and the industry median leverage increase leverage, while R\&D, agency costs (as inverse of TURNOVER), and RISK decrease leverage. Finally, the results support the trade-off theory, as indicated in the bottom panel of each Table.

The bottom panel reports the estimates of the interaction terms between the determinants of the SOA and lagged leverage. Note that Eq. (6) specifies a negative sign on the interaction terms and, therefore, we must interpret the signs of the estimated coefficients accordingly. That is, a negative sign on the interaction term implies a faster adjustment speed (or a positive relation) and a positive sign implies a lower adjustment speed (or a negative relationship) See Drobetz and Wanzenried (2006).

Our findings confirm the hypothesis that SOA is heterogeneous, and significantly affected by the distance from the target, the firm size, growth opportunities, agency costs, and the default risk. In general, the estimates do not appear sensitive to the methods employed. Although not 
reported, the Wald test that all five interaction terms equal zero rejects the homogeneity hypothesis of the SOA at the 1-percent level in all five methods.

The distance from the target capital structure positively and significantly affects the SOA, both individually (column 1) and jointly (column 6) in all five estimation methods. This robust finding implies that the further the observed leverage ratio is from the target, the faster is the SOA. Thus, in the ICT sector, the cost of maintaining a suboptimal leverage exceeds the cost of adjustment, and the fixed costs are not significant. This finding corroborates the findings of Drobetz and Wanzenreid (2006).

We find weak evidence that agency costs associate with a lower SOA, as the interaction term with asset turnover is positive, but only significant in the DPF and SYS-GMM methods. In the LSDVC, BCFE, and QML methods, the interaction term with asset turnover has the correct sign but is not individually significant (column 2) and, in the joint estimation (column 6), the interaction term is significant at the 5-percent level only for the LSDVC method. Since we treat the DPF estimates as our main results, we conclude that agency costs play a role in the ICT firms capital-structure adjustment decisions. An increase in agency costs results in higher adjustment costs, reducing the SOA.

We find a positive relationship between firm size and the SOA only in the DPF method. Thus, according to the estimates of the interaction term with firm size, firm size enhances the SOA. This supports the hypothesis that large firms experience relatively lower adjustment costs than small firms, due to less asymmetric information. Moreover, it indicates that the potential cost of financial distress, which is likely lower for larger firms, is an important factor in the adjustment decisions in ICT firms. We do not confirm this finding, however, in the remaining methods. 
Growth opportunities positively relates to the SOA, which confirms the findings of Drobetz and Wanzenreid (2006) that growing firms adjust faster. Growing firms find it easier to adjust capital structure due to low asymmetric information problems. This finding is robust across the five methodologies.

Finally, default risk exerts a negative effect on the SOA, suggesting that firms with higher financial distress are less likely to adjust their capital structure. This finding is also robust across the five methodologies and confirms the findings of Rashid (2016).

Except for distance, the determinants of the SOA are also significant determinants of the capital structure. Thus, our findings suggest that significant triad relations exist between leverage, firm size, and the SOA; between leverage, growth opportunities, and the SOA; between leverage, agency costs, and the SOA; and between leverage, default risk, and the SOA. Firm size and growth opportunities positively relate to both leverage and the SOA, while agency costs and default risk negatively relate to both leverage and the SOA.

We conduct the same robustness checks that we did in the homogeneous case. First, we estimate the model excluding firms in the software industry. Second, we estimate the model excluding firms in the service sector. Third, we estimate the model excluding the semiconductor industry. We report, for reasons of space, only the results using the DPF method in Tables 13-15. We find that the results are materially unchanged. The findings using the LSDVC, BCFE, QML, and SYS-GMM methods provide similar conclusions and are available from the authors.

\section{Conclusions}

We examine the capital structure of 85 ICT firms over the period 1990-2013. Our empirical analysis leads to the following conclusions. Contrary to the conventional dynamic adjustment models, we estimate SOA as a function of observable factors affecting the adjustment costs, some of which 
partially overlap with the factors determining the target leverage. We conclusively find new and significant evidence that the SOA is heterogeneous. The trade-off and pecking-order theories are silent on the determinants of the SOA. Conversely, we find that distance from the target, firm growth, and firm size are important determinant of the SOA. We find significant positive connections between SOA and distance from the target, firm growth, and firm size. This confirms the finding of Drobetz and Wanzenreid (2006). Moreover, we contribute to this new development in the capital structure literature by providing new evidence on agency costs and default risk as additional determinants of the SOA. We find that agency costs and default risk exert a significant negative effect on the SOA.

In addition, we find significant evidence that agency costs, profitability, firm size, firm growth, $R \& D$ investment, default risk, and the industry median leverage significantly determine the target leverage in ICT firms. The SOA to target leverage is higher in the ICT sector than in other industries. The presence of agency costs, asymmetric information in debt markets, and default risk considerations in capital structure decisions in ICT firms help to understand why firms do not aggressively act to rebalance the capital structure. Managers must carefully consider both the magnitude of their agency costs, the extent of informational asymmetries, and the solvency of their business activities when making financing decisions.

Finally, our results are robust to the alternative methodologies that the econometric literature has developed in the last few years and do not materially differ when we remove the software industry, or the service sector of ICT, or the telecommunication industry from the sample. 
Table 1. Sector distribution of the ICT sample

\begin{tabular}{lc}
\hline Sector & No. of firms \\
\hline Telecommunication Equipment (8030) & 10 \\
System Software (8140) and Application Software (8130) & 10 \\
Semiconductors (8230) and Semiconductor Equipment (8220) & 19 \\
Computer Hardware (8050) and Computer Storage and Peripherals (8052) & 8 \\
Electronic Manufacturing Services (8200) and Consulting Services (8120) & 16 \\
Electronic Equipment and Instruments (8150) & 18 \\
Technology Distributors (8210) & 4 \\
\hline
\end{tabular}

Notes: The data comprise 85 U.S. firms from the Compustat Economic Sector Code 8000 (Information and Communication Technology). The industry sector code is in parentheses.

Table 2. Descriptive Statistics

\begin{tabular}{lccccc}
\hline Variable & Obs & Mean & Std.Dev & Min & Max \\
\hline LEVERAGE & 2064 & 0.38 & 0.199 & 0 & 0.922 \\
GROWTH & 1978 & 0.097 & 0.234 & -1.053 & 1.729 \\
ROA & 2064 & 0.044 & 0.123 & -1.540 & 0.530 \\
SIZE & 2064 & 6.196 & 2.720 & 0.309 & 11.866 \\
R\&D & 2033 & 0.093 & 0.115 & 0.000 & 2.779 \\
TURNOVER & 2064 & 1.108 & 0.728 & 0.013 & 6.225 \\
RISK & 2064 & 0.014 & 0.077 & 0.000 & 2.209 \\
MEDIAN & 2064 & 0.365 & 0.100 & 0.184 & 0.690 \\
\hline
\end{tabular}

Notes: The sample includes 85 U.S. firms that belong to the Compustat Economic Sector 8000. The data are collected over the 24-year period from 1990 to 2013. Leverage is the sum of long-term debt (Compustat item no. 9) and short-term debt (Compustat item no. 12) divided by total assets (Compustat item no. 6). R\&D is R\&D expenditures (Compustat item no. 46) divided by net sales (Compustat item no. 12). Growth is firm growth, computed as the logarithmic first difference of total assets (Compustat item no. 6). ROA is computed as income before extraordinary items (Compustat item no. 18) divided by stockholders' equity (Compustat item no. 6). Total assets (Compustat item no. 6) is the sum of current assets, net property, plant, and equipment, and other noncurrent assets (including intangible assets, deferred items, and investments and advances). Size is the natural log of total assets (Compustat item no. 6). Sales is net sales (Compustat item no. 12), that is the amount of sales after the deduction of returns, allowances for damaged or missing goods and any discounts allowed. Asset turnover is net sales (Compustat item no. 12) divided by total assets (Compustat item no. 6). 
Table 3. OLS and FE estimates of the dynamic adjustment model: the homogeneous case

\begin{tabular}{|c|c|c|}
\hline & OLS & $\mathrm{FE}$ \\
\hline \multirow[t]{2}{*}{$L_{i t-1}$} & $0.838^{* * *}$ & $0.729 * * *$ \\
\hline & $(0.010)$ & $(0.014)$ \\
\hline \multirow[t]{2}{*}{$G_{R O W T H}$} & $0.087 * * *$ & $0.092 * * *$ \\
\hline & $(0.008)$ & (0.008) \\
\hline \multirow[t]{2}{*}{$R O A_{i t}$} & $-0.366^{* * *}$ & $-0.451 * * *$ \\
\hline & $(0.019)$ & $(0.022)$ \\
\hline \multirow[t]{2}{*}{$S I Z E_{i t}$} & $0.007 * * *$ & $0.014 * * *$ \\
\hline & $(0.000)$ & $(0.002)$ \\
\hline \multirow[t]{2}{*}{$R \& D_{i t}$} & $-0.082 * * *$ & $-0.054 * * *$ \\
\hline & $(0.015)$ & $(0.018)$ \\
\hline \multirow[t]{2}{*}{ TURNOVER $_{i t}$} & $0.008 * * *$ & $0.026^{* * *}$ \\
\hline & $(0.002)$ & $(0.006)$ \\
\hline \multirow[t]{2}{*}{$R I S K_{i t}$} & $-0.125 * * *$ & $-0.193 * * *$ \\
\hline & $(0.026)$ & $(0.028)$ \\
\hline \multirow[t]{2}{*}{ MEDIAN $_{t}$} & $0.096^{* * *}$ & $0.195^{* * *}$ \\
\hline & $(0.019)$ & $(0.033)$ \\
\hline Year Effects & Yes & Yes \\
\hline SOA & $16.2 \%$ & $27.1 \%$ \\
\hline Half-Life & 3.9 years & 2.2 years \\
\hline
\end{tabular}


Table 4. Alternative estimates of the dynamic partial adjustment model: the homogeneous case

\begin{tabular}{lccccc}
\hline & DPF & LSDVC & BCFE & QML & SYS-GMM \\
\hline$L_{i t-1}$ & $0.800^{* * *}$ & $0.807^{* * *}$ & $0.795^{* * *}$ & $0.755^{* * *}$ & $0.804^{* * *}$ \\
& $(0.016)$ & $(0.015)$ & $(0.014)$ & $(0.018)$ & $(0.033)$ \\
GROWTH $H_{i t}$ & $0.097^{* * *}$ & $0.096^{* * *}$ & $0.094^{* * *}$ & $0.078^{* * *}$ & $0.081^{* * *}$ \\
& $(0.008)$ & $(0.006)$ & $(0.008)$ & $(0.009)$ & $(0.022)$ \\
ROA $_{i t}$ & $-0.449^{* * *}$ & $-0.442^{* * *}$ & $-0.446^{* * *}$ & $-0.417^{* * *}$ & $-0.374^{* * *}$ \\
& $(0.022)$ & $(0.017)$ & $(0.023)$ & $(0.024)$ & $(0.036)$ \\
SIZE $_{i t}$ & $0.012^{* * *}$ & $0.012^{* *}$ & $0.012^{* * *}$ & $0.011^{* * *}$ & $0.008^{* * *}$ \\
& $(0.003)$ & $(0.003)$ & $(0.003)$ & $(0.003)$ & $(0.002)$ \\
$R \& D_{i t}$ & $-0.047^{* *}$ & $-0.052^{* *}$ & $-0.045^{* *}$ & $-0.013^{* * *}$ & $-0.061^{* *}$ \\
& $(0.018)$ & $(0.023)$ & $(0.020)$ & $(0.004)$ & $(0.027)$ \\
$T U R N O V E R_{i t}$ & $0.021^{* * *}$ & $0.023^{* * *}$ & $0.021^{* * *}$ & $0.033^{* * *}$ & $0.016^{* *}$ \\
& $(0.006)$ & $(0.006)$ & $(0.006)$ & $(0.008)$ & $(0.006)$ \\
$R I S K_{i t}$ & $-0.183^{* * *}$ & $-0.181^{* * *}$ & $-0.185^{* * *}$ & $-0.177^{* * *}$ & $-0.139^{* * * *}$ \\
& $(0.028)$ & $(0.023)$ & $(0.028)$ & $(0.028)$ & $(0.039)$ \\
MEDIAN & $0.176^{* * *}$ & $0.175^{* * *}$ & $0.186^{* * *}$ & $0.168^{* * *}$ & $0.123^{* * *}$ \\
& $(0.033)$ & $(0.032)$ & $(0.037)$ & $(0.037)$ & $(0.034)$ \\
Year Effects & Yes & Yes & Yes & Yes & Yes \\
SOA & $20.0 \%$ & $19.3 \%$ & $20.5 \%$ & $24.5 \%$ & $19.6 \%$ \\
Half-Life & 3.1 years & 3.2 years & 3.0 years & 2.5 years & 3.2 years \\
\hline
\end{tabular}

Notes: Standard errors in parentheses. ${ }^{*}, * *$, and $* * *$ indicate significance at the 10,5 , and 1 percent, respectively. The SOA is derived from the coefficient on lagged leverage. Variable definitions are listed in Table 2. The DPF estimator uses a Gauss-Hermite quadrature to approximate the integrals in the log likelihood function. The standard errors of the LSDVC estimates are obtained from a bootstrap variance-covariance matrix using 50 repetitions. We obtain the initial estimates in the LSDVC estimation using the Blundell and Bond (2000) estimator. The standard errors of the BCFE estimates are approximated by the bootstrap distribution of the fixed-effects estimator. The SYS-GMM model is estimated using the forward orthogonal deviation transformation. The reported standard errors are the robust Windmeijer (2005) finite-sample corrected standard errors. The validity of the instruments is satisfied by the Hansen (1982) test $(\mathrm{p}=0.360)$. The hypothesis of no second order autocorrelation is accepted $(\mathrm{p}=0.181)$. 
Table 5. Alternative estimates of the dynamic partial adjustment model (excluding software): the homogeneous case

\begin{tabular}{|c|c|c|c|c|c|}
\hline & DPF & LSDVC & BCFE & QML & SYS-GMM \\
\hline$L_{i t-1}$ & $\begin{array}{c}0.788 * * * \\
(0.017)\end{array}$ & $\begin{array}{c}0.797 * * * \\
(0.017)\end{array}$ & $\begin{array}{c}0.782 * * * \\
(0.015)\end{array}$ & $\begin{array}{c}0.756 * * * \\
(0.018)\end{array}$ & $\begin{array}{c}0.783 * * * \\
(0.034)\end{array}$ \\
\hline GROWTH $_{i t}$ & $\begin{array}{c}0.115^{* * * *} \\
(0.008)\end{array}$ & $\begin{array}{c}0.114 * * * \\
(0.009)\end{array}$ & $\begin{array}{c}0.113 * * * \\
(0.009)\end{array}$ & $\begin{array}{c}0.117 * * * \\
(0.009)\end{array}$ & $\begin{array}{c}0.102 * * * \\
(0.026)\end{array}$ \\
\hline$R O A_{i t}$ & $\begin{array}{c}-0.491 * * * \\
(0.024)\end{array}$ & $\begin{array}{c}-0.485^{* * *} \\
(0.028)\end{array}$ & $\begin{array}{c}-0.491 * * * \\
(0.025)\end{array}$ & $\begin{array}{c}-0.484 * * * \\
(0.025)\end{array}$ & $\begin{array}{c}-0.433 * * * \\
(0.039)\end{array}$ \\
\hline$S I Z E_{i t}$ & $\begin{array}{c}0.013 * * * \\
(0.003)\end{array}$ & $\begin{array}{l}0.014 * * \\
(0.003)\end{array}$ & $\begin{array}{c}0.013 * * * \\
(0.003)\end{array}$ & $\begin{array}{l}0.014 * \\
(0.003)\end{array}$ & $\begin{array}{c}0.008 * * * \\
(0.002)\end{array}$ \\
\hline$R \& D_{i t}$ & $\begin{array}{c}-0.050 * * \\
(0.019)\end{array}$ & $\begin{array}{c}-0.056^{* *} \\
(0.017)\end{array}$ & $\begin{array}{c}-0.051^{* * *} \\
(0.019)\end{array}$ & $\begin{array}{c}-0.068^{* * *} \\
(0.04)\end{array}$ & $\begin{array}{c}-0.073 * * \\
(0.032)\end{array}$ \\
\hline TURNOVER $_{i t}$ & $\begin{array}{c}0.024 * * * \\
(0.006)\end{array}$ & $\begin{array}{c}0.026^{* * *} \\
(0.007)\end{array}$ & $\begin{array}{c}0.025 * * * \\
(0.006)\end{array}$ & $\begin{array}{c}0.025 * * * \\
(0.006)\end{array}$ & $\begin{array}{c}0.017^{* *} \\
(0.007)\end{array}$ \\
\hline$R I S K_{i t}$ & $\begin{array}{c}-0.215^{* * *} \\
(0.029)\end{array}$ & $\begin{array}{c}-0.214 * * * \\
(0.028)\end{array}$ & $\begin{array}{c}-0.219 * * * \\
(0.029)\end{array}$ & $\begin{array}{c}-0.201 * * * \\
(0.028)\end{array}$ & $\begin{array}{c}-0.177 * * * \\
(0.040)\end{array}$ \\
\hline MEDIAN $_{t}$ & $\begin{array}{c}0.203 * * * \\
(0.036)\end{array}$ & $\begin{array}{c}0.204^{* * *} \\
(0.038)\end{array}$ & $\begin{array}{c}0.209 * * * \\
(0.038)\end{array}$ & $\begin{array}{c}0.225^{* * *} \\
(0.036)\end{array}$ & $\begin{array}{c}0.122 * * * \\
(0.038)\end{array}$ \\
\hline Year Effects & Yes & Yes & Yes & Yes & Yes \\
\hline $\begin{array}{l}\text { SOA } \\
\text { Half-Life }\end{array}$ & $\begin{array}{c}21.2 \% \\
2.9 \text { years }\end{array}$ & $\begin{array}{c}20.3 \% \\
3.1 \text { years }\end{array}$ & $\begin{array}{c}22.7 \% \\
2.8 \text { years }\end{array}$ & $\begin{array}{c}24.4 \% \\
2.5 \text { years }\end{array}$ & $\begin{array}{c}21.7 \% \\
2.8 \text { years }\end{array}$ \\
\hline
\end{tabular}

Notes: Standard errors in parentheses. ${ }^{*}, * *$, and $* * *$ indicate significance at the 10,5 , and 1 percent, respectively. The SOA is derived from the coefficient on lagged leverage. Variable definitions are listed in Table 2. The DPF estimator uses a Gauss-Hermite quadrature to approximate the integrals in the log likelihood function. The standard errors of the LSDVC estimates are obtained from a bootstrap variance-covariance matrix using 50 repetitions. We obtain the initial estimates in the LSDVC estimation using the Blundell and Bond (2000) estimator. The standard errors of the BCFE estimates are approximated by the bootstrap distribution of the fixed-effects estimator. The SYS-GMM model is estimated using the forward orthogonal deviation transformation. The reported standard errors are the robust Windmeijer (2005) finite-sample corrected standard errors. The validity of the instruments is satisfied by the Hansen (1982) test ( $p=0.416)$. The hypothesis of no second order autocorrelation is accepted $(\mathrm{p}=0.119)$. 
Table 6. Alternative estimates of the dynamic partial adjustment model (excluding services): the homogeneous case

\begin{tabular}{|c|c|c|c|c|c|}
\hline & DPF & LSDVC & BCFE & QML & GMM \\
\hline \multirow{2}{*}{$L_{i t-1}$} & $0.782 * * *$ & $0.793 * * *$ & $0.779 * * *$ & $0.763 * * *$ & $0.778 * * *$ \\
\hline & $(0.019)$ & $(0.020)$ & $(0.017)$ & $(0.021)$ & $(0.046)$ \\
\hline \multirow[t]{2}{*}{$\mathrm{GROWTH}_{i t}$} & $0.069 * * *$ & $0.066^{* * *}$ & $0.067 * * *$ & $0.069 * * *$ & $0.052 * * *$ \\
\hline & $(0.009)$ & $(0.008)$ & (0.009) & (0.009) & $(0.021)$ \\
\hline \multirow[t]{2}{*}{$R O A_{i t}$} & $-0.423 * * *$ & $-0.416 * * *$ & $-0.421 * * *$ & $-0.438 * * *$ & $-0.356 * * *$ \\
\hline & $(0.025)$ & $(0.021)$ & $(0.026)$ & $(0.026)$ & $(0.039)$ \\
\hline \multirow[t]{2}{*}{$S I Z E_{i t}$} & $0.013 * * *$ & $0.013 * *$ & $0.013 * * *$ & $0.014 * * *$ & $0.009 * * *$ \\
\hline & $(0.003)$ & $(0.003)$ & $(0.004)$ & $(0.003)$ & $(0.002)$ \\
\hline \multirow[t]{2}{*}{$R \& D_{i t}$} & $-0.046^{* *}$ & $-0.051 * *$ & $-0.049 * *$ & $-0.110 * * *$ & $-0.061 * *$ \\
\hline & $(0.019)$ & $(0.022)$ & (0.019) & $(0.042)$ & $(0.028)$ \\
\hline \multirow[t]{2}{*}{ TURNOVER $_{i t}$} & $0.030 * * *$ & $0.030 * * *$ & $0.029 * * *$ & $0.030 * * *$ & $0.030 * * *$ \\
\hline & $(0.009)$ & $(0.009)$ & $(0.010)$ & $(0.010)$ & $(0.011)$ \\
\hline \multirow[t]{2}{*}{$R I S K_{i t}$} & $-0.179 * * *$ & $-0.176^{* * *}$ & $-0.180 * * *$ & $-0.179 * * *$ & $-0.139 * * *$ \\
\hline & $(0.029)$ & $(0.028)$ & $(0.030)$ & $(0.029)$ & $(0.043)$ \\
\hline \multirow[t]{2}{*}{$M_{E D I A N_{t}}$} & $0.157 * * *$ & $0.155^{* * *}$ & $0.164 * * *$ & $0.185^{* * *}$ & $0.123 * * *$ \\
\hline & $(0.041)$ & $(0.034)$ & $(0.043)$ & $(0.043)$ & $(0.044)$ \\
\hline Year Effects & Yes & Yes & Yes & Yes & Yes \\
\hline SOA & $21.8 \%$ & $20.7 \%$ & $22.1 \%$ & $23.7 \%$ & $22.2 \%$ \\
\hline Half-Life & 2.8 years & 2.9 years & 2.7 years & 2.6 years & 2.7 years \\
\hline \multicolumn{6}{|c|}{$\begin{array}{l}\text { Notes: Standard errors in parentheses. } *, * * \text {, and } * * * \text { indicate significance at the } 10,5 \text {, and } 1 \text { percent, respectively. } \\
\text { The SOA is derived from the coefficient on lagged leverage. Variable definitions are listed in Table } 2 \text {. The } \\
\text { DPF estimator uses a Gauss-Hermite quadrature to approximate the integrals in the log likelihood function. } \\
\text { The standard errors of the LSDVC estimates are obtained from a bootstrap variance-covariance matrix using } \\
50 \text { repetitions. We obtain the initial estimates in the LSDVC estimation using the Blundell and Bond }(2000) \\
\text { estimator. The standard errors of the BCFE estimates are approximated by the bootstrap distribution of the } \\
\text { fixed-effects estimator. The SYS-GMM model is estimated using the forward orthogonal deviation } \\
\text { transformation. The reported standard errors are the robust Windmeijer (2005) finite-sample corrected } \\
\text { standard errors. The validity of the instruments is satisfied by the Hansen (1982) test (p=0.708). The } \\
\text { hypothesis of no second order autocorrelation is accepted ( } \mathrm{p}=0.185) \text {. }\end{array}$} \\
\hline
\end{tabular}


Table 7. Alternative estimates of the dynamic partial adjustment model (excluding semiconductors): the homogeneous case

\begin{tabular}{|c|c|c|c|c|c|}
\hline & DPF & LSDVC & BCFE & QML & SYS-GMM \\
\hline \multirow[t]{2}{*}{$L_{i t-1}$} & $0.822 * * *$ & $0.838^{* * *}$ & $0.812^{* * * *}$ & $0.767 * * *$ & $0.853 * * *$ \\
\hline & $(0.020)$ & $(0.022)$ & $(0.015)$ & $(0.018)$ & $(0.040)$ \\
\hline \multirow[t]{2}{*}{ GROWTH $_{i t}$} & $0.095^{* * *}$ & $0.094 * * *$ & $0.092 * * *$ & $0.091 * * *$ & $0.071^{* *}$ \\
\hline & (0.009) & $(0.010)$ & $(0.009)$ & (0.009) & (0.028) \\
\hline \multirow{2}{*}{$R O A_{i t}$} & $-0.440 * * *$ & $-0.431 * * *$ & $-0.439 * * *$ & $-0.425^{* * *}$ & $-0.344 * * *$ \\
\hline & $(0.024)$ & $(0.029)$ & $(0.025)$ & $(0.025)$ & $(0.053)$ \\
\hline \multirow[t]{2}{*}{$S_{Z I Z}{ }_{i t}$} & $0.008 * * *$ & $0.008^{* *}$ & $0.008 * *$ & $0.013 * * *$ & $0.007 * * *$ \\
\hline & $(0.003)$ & $(0.003)$ & $(0.003)$ & $(0.003)$ & $(0.002)$ \\
\hline \multirow[t]{2}{*}{$R \& D_{i t}$} & $-0.052 * *$ & $-0.059 * * *$ & $-0.049 * *$ & $-0.128^{* * *}$ & $-0.058 * *$ \\
\hline & $(0.018)$ & $(0.016)$ & $(0.021)$ & $(0.04)$ & $(0.023)$ \\
\hline \multirow[t]{2}{*}{ TURNOVER $_{i t}$} & $0.016^{* * *}$ & $0.017 * * *$ & $0.016^{* *}$ & $0.020 * * *$ & 0.008 \\
\hline & (0.006) & $(0.005)$ & $(0.006)$ & (0.006) & $(0.006)$ \\
\hline \multirow[t]{2}{*}{$R_{I S K_{i t}}$} & $-0.138 * * *$ & $-0.135^{* * *}$ & $-0.140 * * *$ & $-0.092 * *$ & -0.046 \\
\hline & $(0.040)$ & $(0.042)$ & $(0.041)$ & $(0.040)$ & $(0.053)$ \\
\hline \multirow[t]{2}{*}{ MEDIAN $_{t}$} & $0.177 * * *$ & $0.174 * * *$ & $0.192 * * *$ & $0.203^{* * *}$ & $0.091^{* *}$ \\
\hline & $(0.037)$ & $(0.044)$ & $(0.040)$ & (0.038) & (0.034) \\
\hline Year Effects & Yes & Yes & Yes & Yes & Yes \\
\hline SOA & $17.8 \%$ & $16.2 \%$ & $18.7 \%$ & $23.2 \%$ & $14.7 \%$ \\
\hline Half-Life & 3.5 years & 3.9 years & 3.3 years & 2.6 years & 4.3 years \\
\hline
\end{tabular}

Notes: Standard errors in parentheses. *,**, and *** indicate significance at the 10,5, and 1 percent, respectively. The SOA is derived from the coefficient on lagged leverage. Variable definitions are listed in Table 2 . The DPF estimator uses a Gauss-Hermite quadrature to approximate the integrals in the log likelihood function. The standard errors of the LSDVC estimates are obtained from a bootstrap variance-covariance matrix using 50 repetitions. We obtain the initial estimates in the LSDVC estimation using the Blundell and Bond (2000) estimator. The standard errors of the BCFE estimates are approximated by the bootstrap distribution of the fixed-effects estimator. The SYS-GMM model is estimated using the forward orthogonal deviation transformation. The reported standard errors are the robust Windmeijer (2005) finite-sample corrected standard errors. The validity of the instruments is satisfied by the Hansen (1982) test $(\mathrm{p}=0.583)$. The hypothesis of no second order autocorrelation is accepted $(\mathrm{p}=0.129)$. 
Table 8. DPF estimates of the dynamic partial adjustment model: the heterogeneous case

\begin{tabular}{|c|c|c|c|c|c|c|}
\hline & 1 & 2 & 3 & 4 & 5 & 6 \\
\hline & \multicolumn{6}{|c|}{ Determinants of Capital Structure } \\
\hline$L_{i t-1}$ & $\begin{array}{c}0.861 * * * \\
(0.013)\end{array}$ & $\begin{array}{c}0.889 * * * \\
(0.016)\end{array}$ & $\begin{array}{c}0.889 * * * \\
(0.021)\end{array}$ & $\begin{array}{c}0.849 * * * \\
(0.019)\end{array}$ & $\begin{array}{c}0.788 * * * \\
(0.016)\end{array}$ & $\begin{array}{c}0.937 * * * \\
(0.029)\end{array}$ \\
\hline $\mathrm{GROWTH}_{i t}$ & $\begin{array}{c}0.110 * * * \\
(0.008)\end{array}$ & $\begin{array}{c}0.097 * * * \\
(0.008)\end{array}$ & $\begin{array}{c}0.094 * * * \\
(0.008)\end{array}$ & $\begin{array}{c}0.225 * * * \\
(0.016)\end{array}$ & $\begin{array}{c}0.098 * * * \\
(0.008)\end{array}$ & $\begin{array}{c}0.205 * * * \\
(0.015)\end{array}$ \\
\hline$R O A_{i t}$ & $\begin{array}{c}-0.464 * * * \\
(0.022)\end{array}$ & $\begin{array}{c}-0.453 * * * \\
(0.022)\end{array}$ & $\begin{array}{c}-0.448 * * * \\
(0.022)\end{array}$ & $\begin{array}{c}-0.436 * * * \\
(0.022)\end{array}$ & $\begin{array}{c}-0.431 * * * \\
(0.022)\end{array}$ & $\begin{array}{c}-0.438 * * * \\
(0.021)\end{array}$ \\
\hline$S I Z E_{i t}$ & $\begin{array}{c}0.010 * * * \\
(0.002)\end{array}$ & $\begin{array}{c}0.014 * * * \\
(0.003)\end{array}$ & $\begin{array}{c}0.022 * * * \\
(0.003)\end{array}$ & $\begin{array}{c}0.100 * * * \\
(0.002)\end{array}$ & $\begin{array}{c}0.012^{* * *} \\
(0.002)\end{array}$ & $\begin{array}{c}0.017 * * * \\
(0.003)\end{array}$ \\
\hline$R \& D_{i t}$ & $\begin{array}{c}-0.041 * * \\
(0.018)\end{array}$ & $\begin{array}{c}-0.034 * \\
(0.018\end{array}$ & $\begin{array}{c}-0.053 * * * \\
(0.018)\end{array}$ & $\begin{array}{c}-0.035 * \\
(0.018)\end{array}$ & $\begin{array}{c}-0.045^{* *} \\
(0.018)\end{array}$ & $\begin{array}{c}-0.033 * \\
(0.017)\end{array}$ \\
\hline TURNOVER $_{i t}$ & $\begin{array}{c}0.019 * * * \\
(0.006)\end{array}$ & $\begin{array}{c}0.067 * * * \\
(0.009)\end{array}$ & $\begin{array}{c}0.023 * * * \\
(0.006)\end{array}$ & $\begin{array}{c}0.014 * * \\
(0.006)\end{array}$ & $\begin{array}{c}0.021 * * * \\
(0.006)\end{array}$ & $\begin{array}{c}0.035 * * * \\
(0.009)\end{array}$ \\
\hline$R I S K_{i t}$ & $\begin{array}{c}-0.185^{* * *} * \\
(0.027)\end{array}$ & $\begin{array}{c}-0.195 * * * \\
(0.028)\end{array}$ & $\begin{array}{c}-0.183 * * * \\
(0.027)\end{array}$ & $\begin{array}{c}-0.133 * * * \\
(0.028)\end{array}$ & $\begin{array}{c}-0.276^{* * *} * \\
(0.037)\end{array}$ & $\begin{array}{c}-0.225 * * * \\
(0.036)\end{array}$ \\
\hline \multirow[t]{2}{*}{ MEDIAN $_{t}$} & $\begin{array}{c}0.153 * * * \\
(0.033)\end{array}$ & $\begin{array}{c}0.169 * * * \\
(0.033)\end{array}$ & $\begin{array}{c}0.192 * * * \\
(0.033)\end{array}$ & $\begin{array}{c}0.157 * * * \\
(0.033)\end{array}$ & $\begin{array}{c}0.176 * * * \\
(0.033)\end{array}$ & $\begin{array}{c}0.160 * * * \\
(0.032)\end{array}$ \\
\hline & \multicolumn{6}{|c|}{ Determinants of SOA } \\
\hline$L_{i t-1} \times D I S T A N C E_{i t}$ & $\begin{array}{c}-0.605^{* * *} * \\
(0.068)\end{array}$ & & & & & $\begin{array}{c}-0.490 * * * \\
(0.067)\end{array}$ \\
\hline$L_{i t-1} \times T U R N O V E R_{i t}$ & & $\begin{array}{c}-0.092 * * * \\
(0.014)\end{array}$ & & & & $\begin{array}{c}-0.040 * * * \\
(0.015)\end{array}$ \\
\hline$L_{i t-1} \times S I Z E_{i t}$ & & & $\begin{array}{c}-0.021 * * * \\
(0.003)\end{array}$ & & & $\begin{array}{c}-0.013 * * * \\
(0.004)\end{array}$ \\
\hline$L_{i t-1} \times G R O W T H_{i t}$ & & & & $\begin{array}{c}-0.365 * * * \\
(0.039)\end{array}$ & & $\begin{array}{c}-0.292^{* * *} \\
(0.038)\end{array}$ \\
\hline$L_{i t-1} \times R I S K_{i t}$ & & & & & $\begin{array}{c}0.727 * * * \\
(0.194)\end{array}$ & $\begin{array}{c}0.549 * * * \\
(0.189)\end{array}$ \\
\hline
\end{tabular}


Table 9. LSDVC estimates of the dynamic partial adjustment model: the heterogeneous case

\begin{tabular}{|c|c|c|c|c|c|c|}
\hline & 1 & 2 & 3 & 4 & 5 & 6 \\
\hline & \multicolumn{6}{|c|}{ Determinants of Capital Structure } \\
\hline$L_{i t-1}$ & $\begin{array}{c}0.869^{* * * *} \\
(0.015)\end{array}$ & $\begin{array}{c}0.825 * * * \\
(0.017)\end{array}$ & $\begin{array}{c}0.818 * * * \\
(0.018)\end{array}$ & $\begin{array}{c}0.840 * * * \\
(0.015)\end{array}$ & $\begin{array}{l}0.797 * * \\
(0.014)\end{array}$ & $\begin{array}{c}0.953 * * * \\
(0.015)\end{array}$ \\
\hline GROWTH $_{i t}$ & $\begin{array}{c}0.107 * * * \\
(0.007)\end{array}$ & $\begin{array}{c}0.095^{* * * *} \\
(0.006)\end{array}$ & $\begin{array}{c}0.094 * * * \\
(0.006)\end{array}$ & $\begin{array}{c}0.208 * * * \\
(0.014)\end{array}$ & $\begin{array}{c}0.097 * * * \\
(0.006)\end{array}$ & $\begin{array}{c}0.203 * * * \\
(0.014)\end{array}$ \\
\hline$R O A_{i t}$ & $\begin{array}{c}-0.453 * * * \\
(0.024)\end{array}$ & $\begin{array}{c}-0.443 * * * \\
(0.017)\end{array}$ & $\begin{array}{c}-0.440 * * * \\
(0.016)\end{array}$ & $\begin{array}{c}-0.433 * * * \\
(0.016)\end{array}$ & $\begin{array}{c}-0.423^{* * *} \\
(0.018)\end{array}$ & $\begin{array}{c}-0.432 * * * * \\
(0.025)\end{array}$ \\
\hline$S I Z E_{i t}$ & $\begin{array}{c}0.010^{* * * *} \\
(0.004)\end{array}$ & $\begin{array}{c}0.013 * * * \\
(0.003)\end{array}$ & $\begin{array}{c}0.014 * * * \\
(0.003)\end{array}$ & $\begin{array}{c}0.011 * * * \\
(0.003)\end{array}$ & $\begin{array}{c}0.013 * * * \\
(0.003)\end{array}$ & $\begin{array}{c}0.012 * * * \\
(0.004)\end{array}$ \\
\hline$R \& D_{i t}$ & $\begin{array}{c}-0.049 * * * \\
(0.015)\end{array}$ & $\begin{array}{c}-0.052^{* *} \\
(0.023)\end{array}$ & $\begin{array}{c}-0.055^{* *} \\
(0.024)\end{array}$ & $\begin{array}{c}-0.045^{* *} \\
(0.022)\end{array}$ & $\begin{array}{c}-0.051^{* *} \\
(0.023)\end{array}$ & $\begin{array}{c}-0.043^{* * * *} \\
(0.167)\end{array}$ \\
\hline TURNOVER $_{i t}$ & $\begin{array}{c}0.020^{* * * *} \\
(0.005)\end{array}$ & $\begin{array}{c}0.030^{* * * *} \\
(0.010)\end{array}$ & $\begin{array}{c}0.024 * * * \\
(0.006)\end{array}$ & $\begin{array}{l}0.017 * * \\
(0.006)\end{array}$ & $\begin{array}{c}0.023 * * * \\
(0.006)\end{array}$ & $\begin{array}{c}0.031^{* * * *} \\
(0.009)\end{array}$ \\
\hline$R I S K_{i t}$ & $\begin{array}{c}-0.182 * * * \\
(0.025)\end{array}$ & $\begin{array}{c}-0.184 * * * \\
(0.024)\end{array}$ & $\begin{array}{c}-0.182 * * * \\
(0.022)\end{array}$ & $\begin{array}{c}-0.139 * * * \\
(0.023)\end{array}$ & $\begin{array}{c}-0.283 * * * \\
(0.034)\end{array}$ & $\begin{array}{c}-0.224 * * * \\
(0.031)\end{array}$ \\
\hline MEDIAN $_{t}$ & $\begin{array}{c}0.158 * * * \\
(0.033)\end{array}$ & $\begin{array}{c}0.171 * * * \\
(0.032)\end{array}$ & $\begin{array}{c}0.179 * * * \\
(0.032) \\
\text { Determin }\end{array}$ & $\begin{array}{c}0.164 * * * \\
(0.031) \\
\text { nts of SOA }\end{array}$ & $\begin{array}{c}0.174 * * * \\
(0.032)\end{array}$ & $\begin{array}{c}0.153 * * * \\
(0.030)\end{array}$ \\
\hline$L_{i t-1} \times D_{I S T A N C E}$ & $\begin{array}{c}-0.512 * * * \\
(0.071)\end{array}$ & & & & & $\begin{array}{c}-0.499 * * * \\
(0.081)\end{array}$ \\
\hline$L_{i t-1} \times T U R N O V E R_{i t}$ & & $\begin{array}{l}-0.014 \\
(0.014)\end{array}$ & & & & $\begin{array}{c}-0.034 * * \\
(0.013)\end{array}$ \\
\hline$L_{i t-1} \times S I Z E_{i t}$ & & & $\begin{array}{l}-0.003 \\
(0.002)\end{array}$ & & & $\begin{array}{l}-0.006^{*} \\
(0.003)\end{array}$ \\
\hline$L_{i t-1} \times G R O W T H_{i t}$ & & & & $\begin{array}{c}-0.321 * * * \\
(0.039)\end{array}$ & & $\begin{array}{c}-0.277 * * \\
(0.034)\end{array}$ \\
\hline$L_{i t-1} \times R I S K_{i t}$ & & & & & $\begin{array}{l}0.794 * * * \\
(0.250) \\
\end{array}$ & $\begin{array}{l}0.57 * * * \\
(0.167)\end{array}$ \\
\hline
\end{tabular}

Notes: Standard errors in parentheses. *, **, and *** indicate significance at the 10, 5, and 1 percent, respectively. Variable definitions are listed in Table 2. The standard errors of the LSDVC estimates are obtained from a bootstrap variance-covariance matrix using 50 repetitions. We obtain the initial estimates in the LSDVC estimation using the Blundell and Bond (2000) estimator. 
Table 10. BCFE estimates of the dynamic partial adjustment model: the heterogeneous case

\begin{tabular}{|c|c|c|c|c|c|c|}
\hline & $\mathbf{1}$ & 2 & 3 & 4 & 5 & 6 \\
\hline & \multicolumn{6}{|c|}{ Determinants of Capital Structure } \\
\hline$L_{i t-1}$ & $\begin{array}{c}0.848 * * * \\
(0.014)\end{array}$ & $\begin{array}{c}0.794 * * * \\
(0.015)\end{array}$ & $\begin{array}{c}0.800 * * * \\
(0.015)\end{array}$ & $\begin{array}{c}0.828^{* * * *} \\
(0.014)\end{array}$ & $\begin{array}{c}0.785^{* * * *} \\
(0.014)\end{array}$ & $\begin{array}{c}0.915 * * * \\
(0.013)\end{array}$ \\
\hline GROWTH $_{i t}$ & $\begin{array}{c}0.106^{* * *} \\
(0.008)\end{array}$ & $\begin{array}{c}0.093 * * * \\
(0.008)\end{array}$ & $\begin{array}{c}0.093 * * * \\
(0.008)\end{array}$ & $\begin{array}{c}0.204 * * * \\
(0.014)\end{array}$ & $\begin{array}{c}0.096^{* * *} \\
(0.008)\end{array}$ & $\begin{array}{c}0.208^{* * *} \\
(0.016)\end{array}$ \\
\hline$R O A_{i t}$ & $\begin{array}{c}-0.460 * * * \\
(0.023)\end{array}$ & $\begin{array}{c}-0.446^{* * * *} \\
(0.023)\end{array}$ & $\begin{array}{c}-0.445 * * * \\
(0.023)\end{array}$ & $\begin{array}{c}-0.437 * * * \\
(0.023)\end{array}$ & $\begin{array}{c}-0.428^{* * * *} \\
(0.023)\end{array}$ & $\begin{array}{c}-0.439^{* * * *} \\
(0.023)\end{array}$ \\
\hline$S I Z E_{i t}$ & $\begin{array}{c}0.011 * * * \\
(0.003)\end{array}$ & $\begin{array}{c}0.012 * * * \\
(0.003)\end{array}$ & $\begin{array}{c}0.013 * * * \\
(0.003)\end{array}$ & $\begin{array}{c}0.010 * * * \\
(0.003)\end{array}$ & $\begin{array}{c}0.012 * * * \\
(0.003)\end{array}$ & $\begin{array}{c}0.012 * * * \\
(0.003)\end{array}$ \\
\hline$R \& D_{i t}$ & $\begin{array}{c}-0.041 * * \\
(0.019)\end{array}$ & $\begin{array}{c}-0.046^{* *} \\
(0.020)\end{array}$ & $\begin{array}{c}-0.047 * * \\
(0.020)\end{array}$ & $\begin{array}{l}-0.037 * \\
(0.020)\end{array}$ & $\begin{array}{c}-0.042^{* *} \\
(0.020)\end{array}$ & $\begin{array}{l}-0.034 * \\
(0.018)\end{array}$ \\
\hline TURNOVER $_{i t}$ & $\begin{array}{c}0.019 * * * \\
(0.006)\end{array}$ & $\begin{array}{c}0.026^{* * *} \\
(0.009)\end{array}$ & $\begin{array}{c}0.022 * * * \\
(0.006)\end{array}$ & $\begin{array}{c}0.016^{* *} \\
(0.006)\end{array}$ & $\begin{array}{c}0.021 * * * \\
(0.006)\end{array}$ & $\begin{array}{c}0.025^{* *} \\
(0.010)\end{array}$ \\
\hline $\operatorname{RISK}_{i t}$ & $\begin{array}{c}-0.189 * * * \\
(0.027)\end{array}$ & $\begin{array}{c}-0.187 * * * \\
(0.028)\end{array}$ & $\begin{array}{c}-0.186 * * * \\
(0.028)\end{array}$ & $\begin{array}{c}-0.144 * * * \\
(0.028)\end{array}$ & $\begin{array}{c}-0.286^{* * *} \\
(0.036)\end{array}$ & $\begin{array}{c}-0.230 * * * \\
(0.038)\end{array}$ \\
\hline MEDIAN $_{t}$ & $\begin{array}{l}0.17^{* * * *} \\
(0.035)\end{array}$ & $\begin{array}{c}0.187 * * * \\
(0.037)\end{array}$ & $\begin{array}{c}0.190^{* * * *} \\
(0.037) \\
\text { Determin }\end{array}$ & $\begin{array}{c}0.174 * * * \\
(0.036) \\
\text { ts of SOA }\end{array}$ & $\begin{array}{c}0.184 * * * \\
(0.036)\end{array}$ & $\begin{array}{c}0.164 * * * \\
(0.035)\end{array}$ \\
\hline$L_{i t-1} \times$ DISTANCE $E_{i t}$ & $\begin{array}{c}-0.486 * * * \\
(0.065)\end{array}$ & & & & & $\begin{array}{c}-0.466^{* * * *} \\
(0.069)\end{array}$ \\
\hline$L_{i t-1} \times T U R N O V E R_{i t}$ & & $\begin{array}{l}-0.007 \\
(0.012)\end{array}$ & & & & $\begin{array}{l}-0.020 \\
(0.015)\end{array}$ \\
\hline$L_{i t-1} \times S I Z E_{i t}$ & & & $\begin{array}{l}-0.002 \\
(0.002)\end{array}$ & & & $\begin{array}{l}-0.004 \\
(0.003)\end{array}$ \\
\hline$L_{i t-1} \times G R O W T H_{i t}$ & & & & $\begin{array}{c}-0.316 * * * \\
(0.037)\end{array}$ & & $\begin{array}{c}-0.288 * * * \\
(0.040)\end{array}$ \\
\hline$L_{i t-1} \times R I S K_{i t}$ & & & & & $\begin{array}{c}0.784 * * * \\
(0.185)\end{array}$ & $\begin{array}{c}0.593 * * * \\
(0.197)\end{array}$ \\
\hline
\end{tabular}

Notes: Standard errors in parentheses. *, **, and *** indicate significance at the 10, 5, and 1 percent, respectively. Variable definitions are listed in Table 2. The standard errors of the BCFE estimates are approximated by the bootstrap distribution of the fixed-effects estimator. 
Table 11. QML estimates of the dynamic partial adjustment model: the heterogeneous case

\begin{tabular}{|c|c|c|c|c|c|c|}
\hline & 1 & 2 & 3 & 4 & 5 & 6 \\
\hline & \multicolumn{6}{|c|}{ Determinants of Capital Structure } \\
\hline$L_{i t-1}$ & $\begin{array}{c}0.772 * * * \\
(0.019)\end{array}$ & $\begin{array}{c}0.774 * * * \\
(0.029)\end{array}$ & $\begin{array}{c}0.711 * * * \\
(0.037)\end{array}$ & $\begin{array}{c}0.789 * * * \\
(0.018)\end{array}$ & $\begin{array}{c}0.742 * * * \\
(0.018)\end{array}$ & $\begin{array}{c}0.810 * * * \\
(0.056)\end{array}$ \\
\hline GROWTH $_{i t}$ & $\begin{array}{c}0.081 * * * \\
(0.010)\end{array}$ & $\begin{array}{c}0.078 * * * \\
(0.009)\end{array}$ & $\begin{array}{c}0.078 * * * \\
(0.009)\end{array}$ & $\begin{array}{c}0.198 * * * \\
(0.017)\end{array}$ & $\begin{array}{c}0.080 * * * \\
(0.009)\end{array}$ & $\begin{array}{c}0.199 * * * \\
(0.017)\end{array}$ \\
\hline$R O A_{i t}$ & $\begin{array}{c}- \\
0.419 * * * \\
(0.024)\end{array}$ & $\begin{array}{c}-0.417 * * * \\
(0.024)\end{array}$ & $\begin{array}{c}-0.418 * * * \\
(0.024)\end{array}$ & $\begin{array}{c}-0.411 * * * \\
(0.023)\end{array}$ & $\begin{array}{c}-0.404 * * * \\
(0.024)\end{array}$ & $\begin{array}{c}-0.402 * * * \\
(0.024)\end{array}$ \\
\hline$S I Z E_{i t}$ & $\begin{array}{c}0.009 * * * \\
(0.003)\end{array}$ & $\begin{array}{c}0.011 * * * \\
(0.003)\end{array}$ & $\begin{array}{l}0.009 * * \\
(0.003)\end{array}$ & $\begin{array}{c}0.010^{* * * *} \\
(0.003)\end{array}$ & $\begin{array}{c}0.012 * * * \\
(0.003)\end{array}$ & $\begin{array}{c}0.011 * * * \\
(0.003)\end{array}$ \\
\hline$R \& D_{i t}$ & $\begin{array}{c}0.014 * * * \\
(0.004)\end{array}$ & $\begin{array}{c}-0.014 * * * \\
(0.004)\end{array}$ & $\begin{array}{c}-0.013 * * * \\
(0.004)\end{array}$ & $\begin{array}{c}-0.011 * * \\
(0.004)\end{array}$ & $\begin{array}{c}-0.014 * * * \\
(0.004)\end{array}$ & $\begin{array}{c}-0.011 * * \\
(0.004)\end{array}$ \\
\hline TURNOVER ${ }_{i t}$ & $\begin{array}{c}0.030 * * * \\
(0.008)\end{array}$ & $\begin{array}{c}0.042 * * * \\
(0.014)\end{array}$ & $\begin{array}{c}0.035^{* * *} \\
(0.008)\end{array}$ & $\begin{array}{c}0.033 * * * \\
(0.008)\end{array}$ & $\begin{array}{c}0.033 * * * \\
(0.008)\end{array}$ & $\begin{array}{c}0.047 * * * \\
(0.014)\end{array}$ \\
\hline$R_{I S K}$ & $\begin{array}{c}- \\
0.177 * * * \\
(0.028)\end{array}$ & $\begin{array}{c}-0.178 * * * \\
(0.028)\end{array}$ & $\begin{array}{c}-0.179 * * * \\
(0.028)\end{array}$ & $\begin{array}{c}-0.136 * * * \\
(0.028)\end{array}$ & $\begin{array}{c}-0.301 * * * \\
(0.039)\end{array}$ & $\begin{array}{c}-0.226^{* * *} \\
(0.040)\end{array}$ \\
\hline \multirow[t]{2}{*}{ MEDIAN $_{t}$} & $\begin{array}{c}0.160 * * * \\
(0.039)\end{array}$ & $\begin{array}{c}0.168 * * * \\
(0.037)\end{array}$ & $\begin{array}{c}0.161 * * * \\
(0.037)\end{array}$ & $\begin{array}{c}0.160^{* * *} \\
(0.036)\end{array}$ & $\begin{array}{c}0.165^{* * *} \\
(0.037)\end{array}$ & $\begin{array}{c}0.138 * * * \\
(0.038)\end{array}$ \\
\hline & \multicolumn{6}{|c|}{ Determinants of SOA } \\
\hline$L_{i t-1} \times$ DISTANCE $E_{i t}$ & $\begin{array}{l}-0.192 \\
(0.084)\end{array}$ & & & & & $\begin{array}{l}-0.112 \\
(0.083)\end{array}$ \\
\hline$L_{i t-1} \times T U R N O V E R_{i t}$ & & $\begin{array}{l}-0.021 \\
(0.024)\end{array}$ & & & & $\begin{array}{l}-0.032 \\
(0.026)\end{array}$ \\
\hline$L_{i t-1} \times S I Z E_{i t}$ & & & $\begin{array}{c}0.006 \\
(0.005)\end{array}$ & & & $\begin{array}{c}0.001 \\
(0.005)\end{array}$ \\
\hline$L_{i t-1} \times G R O W T H_{i t}$ & & & & $\begin{array}{c}-0.360 * * * \\
(0.043)\end{array}$ & & $\begin{array}{c}-0.355^{* * *} \\
(0.045)\end{array}$ \\
\hline$L_{i t-1} \times R I S K_{i t}$ & & & & & $\begin{array}{c}0.973 * * * \\
(0.211)\end{array}$ & $\begin{array}{c}0.672 * * * \\
(0.213)\end{array}$ \\
\hline
\end{tabular}

Notes: Standard errors in parentheses. *, **, and $* * *$ indicate significance at the 10,5 , and 1 percent, respectively. Variable definitions are listed in Table 2. 
Table 12. SYS-GMM estimates of the dynamic partial adjustment model: the heterogeneous case

\begin{tabular}{|c|c|c|c|c|c|c|}
\hline & 1 & 2 & 3 & 4 & 5 & 6 \\
\hline & \multicolumn{6}{|c|}{ Determinants of Capital Structure } \\
\hline$L_{i t-1}$ & $\begin{array}{c}0.880 * * * \\
(0.02)\end{array}$ & $\begin{array}{c}0.902 * * * \\
(0.028)\end{array}$ & $\begin{array}{c}0.888 * * * \\
(0.058)\end{array}$ & $\begin{array}{c}0.869^{* * *} \\
(0.025)\end{array}$ & $\begin{array}{c}0.835 * * * \\
(0.025)\end{array}$ & $\begin{array}{c}1.075^{* * *} \\
(0.058)\end{array}$ \\
\hline GROWTH $_{i t}$ & $\begin{array}{c}0.074 * * * \\
(0.026)\end{array}$ & $\begin{array}{c}0.074 * * * \\
(0.025\end{array}$ & $\begin{array}{c}0.078 * * * \\
(0.026)\end{array}$ & $\begin{array}{c}0.178^{* * *} * \\
(0.043)\end{array}$ & $\begin{array}{c}0.079 * * * \\
(0.025)\end{array}$ & $\begin{array}{c}0.175^{* * *} \\
(0.047)\end{array}$ \\
\hline$R O A_{i t}$ & $\begin{array}{c}-0.367^{* * * *} \\
(0.047)\end{array}$ & $\begin{array}{c}-0.368 * * * \\
(0.043)\end{array}$ & $\begin{array}{c}-0.358 * * * \\
(0.046)\end{array}$ & $\begin{array}{c}-0.356^{* * * *} \\
(0.045)\end{array}$ & $\begin{array}{c}-0.349 * * * * \\
(0.041)\end{array}$ & $\begin{array}{c}-0.351^{* * *} \\
(0.046)\end{array}$ \\
\hline$S I Z E_{i t}$ & $\begin{array}{c}0.006 * * * \\
(0.001)\end{array}$ & $\begin{array}{c}0.008 * * * \\
(0.001)\end{array}$ & $\begin{array}{c}0.011 * * * \\
(0.002)\end{array}$ & $\begin{array}{c}0.007 * * * \\
(0.001)\end{array}$ & $\begin{array}{c}0.008 * * * \\
(0.001)\end{array}$ & $\begin{array}{c}0.014 * * * \\
(0.002)\end{array}$ \\
\hline$R \& D_{i t}$ & $\begin{array}{c}-0.047 * * * * \\
(0.014)\end{array}$ & $\begin{array}{c}-0.041 * * * * \\
(0.013)\end{array}$ & $\begin{array}{c}-0.060^{* * *} \\
(0.0159)\end{array}$ & $\begin{array}{c}-0.049 * * * \\
(0.016)\end{array}$ & $\begin{array}{c}-0.058^{* * * *} \\
(0.015)\end{array}$ & $\begin{array}{l}-0.027 \\
(0.017)\end{array}$ \\
\hline TURNOVER $_{i t}$ & $\begin{array}{l}0.009^{* *} \\
(0.003)\end{array}$ & $\begin{array}{c}0.044 * * * \\
(0.009)\end{array}$ & $\begin{array}{l}0.011^{*} \\
(0.005)\end{array}$ & $\begin{array}{c}0.010 * * * \\
(0.004)\end{array}$ & $\begin{array}{l}0.011^{* * *} \\
(0.005)\end{array}$ & $\begin{array}{c}0.052 * * * \\
(0.011)\end{array}$ \\
\hline RISK $_{i t}$ & $\begin{array}{c}-0.144 * * * \\
(0.044)\end{array}$ & $\begin{array}{c}-0.155^{* * *} \\
(0.038)\end{array}$ & $\begin{array}{c}-0.126^{* *} \\
(0.048)\end{array}$ & $\begin{array}{c}-0.099 * * \\
(0.045)\end{array}$ & $\begin{array}{c}-0.264 * * * \\
(0.033)\end{array}$ & $\begin{array}{c}-0.208 * * * \\
(0.043)\end{array}$ \\
\hline \multirow[t]{2}{*}{$\operatorname{MEDIAN}_{t}$} & $\begin{array}{c}0.096 * * * \\
(0.031)\end{array}$ & $\begin{array}{c}0.124 * * * \\
(0.033)\end{array}$ & $\begin{array}{c}0.108 * * * \\
(0.035)\end{array}$ & $\begin{array}{c}0.097 * * * \\
(0.030)\end{array}$ & $\begin{array}{c}0.099 * * * \\
(0.033)\end{array}$ & $\begin{array}{c}0.083 * * * \\
(0.026)\end{array}$ \\
\hline & \multicolumn{6}{|c|}{ Determinants of SOA } \\
\hline$L_{i t-1} \times$ DISTANCE & $\begin{array}{l}-0.456^{*} \\
(0.273)\end{array}$ & & & & & $\begin{array}{l}-0.537 * * \\
(0.0262)\end{array}$ \\
\hline$L_{i t-1} \times T U R N O V E R_{i t}$ & & $\begin{array}{c}-0.063 * * * \\
(0.017)\end{array}$ & & & & $\begin{array}{c}-0.075^{* * *} \\
(0.022)\end{array}$ \\
\hline$L_{i t-1} \times S I Z E_{i t}$ & & & $\begin{array}{l}-0.008 \\
(0.007)\end{array}$ & & & $\begin{array}{c}-0.015^{* *} \\
(0.006)\end{array}$ \\
\hline$L_{i t-1} \times G R O W T H_{i t}$ & & & & $\begin{array}{c}-0.300 * * * \\
(0.072)\end{array}$ & & $\begin{array}{c}-0.269 * * * \\
(0.091)\end{array}$ \\
\hline$L_{i t-1} \times R I S K_{i t}$ & & & & & $\begin{array}{c}1.011 * * * \\
(0.285)\end{array}$ & $\begin{array}{c}0.798 * * \\
(0.350)\end{array}$ \\
\hline
\end{tabular}

Notes: Standard errors in parentheses. ${ }^{*}, * *$, and $* * *$ indicate significance at the 10,5 , and 1 percent, respectively. Variable definitions are listed in Table 2. The SYS-GMM model is estimated using the forward orthogonal deviation transformation. The reported standard errors are the robust Windmeijer (2005) finite-sample corrected standard errors. In all cases, the validity of the instruments is satisfied by the Hansen (1982) test and the hypothesis of no second order autocorrelation is accepted. 
Table 13. DPF Estimates of the dynamic partial adjustment model (excluding software): the heterogeneous case

\begin{tabular}{|c|c|c|c|c|c|c|}
\hline & 1 & 2 & 3 & 4 & 5 & 6 \\
\hline & \multicolumn{6}{|c|}{ Determinants of capital structure } \\
\hline$L_{i t-1}$ & $\begin{array}{c}0.865^{* * *} \\
(0.013)\end{array}$ & $\begin{array}{c}0.874 * * * \\
(0.017)\end{array}$ & $\begin{array}{c}0.899 * * * \\
(0.022)\end{array}$ & $\begin{array}{c}0.838^{* * *} \\
(0.019)\end{array}$ & $\begin{array}{c}0.778 * * * \\
(0.017)\end{array}$ & $\begin{array}{c}0.955^{* * *} \\
(0.031)\end{array}$ \\
\hline GROWTH $_{i t}$ & $\begin{array}{c}0.132 * * * \\
(0.009)\end{array}$ & $\begin{array}{c}0.115^{* * *} \\
(0.009)\end{array}$ & $\begin{array}{c}0.112 * * * \\
(0.009)\end{array}$ & $\begin{array}{c}0.255^{* * *} \\
(0.017)\end{array}$ & $\begin{array}{c}0.116^{* * *} \\
(0.009)\end{array}$ & $\begin{array}{c}0.239 * * * \\
(0.016)\end{array}$ \\
\hline$R O A_{i t}$ & $\begin{array}{c}-0.509 * * * \\
(0.023)\end{array}$ & $\begin{array}{c}-0.493 * * * \\
(0.024)\end{array}$ & $\begin{array}{c}-0.491 * * * \\
(0.023)\end{array}$ & $\begin{array}{c}-0.477 * * * \\
(0.023)\end{array}$ & $\begin{array}{c}-0.472 * * * \\
(0.024)\end{array}$ & $\begin{array}{c}-0.484 * * * \\
(0.023)\end{array}$ \\
\hline$S I Z E_{i t}$ & $\begin{array}{c}0.011 * * * \\
(0.003)\end{array}$ & $\begin{array}{c}0.015^{* * *} \\
(0.003)\end{array}$ & $\begin{array}{c}0.025^{* * *} \\
(0.003)\end{array}$ & $\begin{array}{c}0.011^{* * *} \\
(0.003)\end{array}$ & $\begin{array}{c}0.014 * * * \\
(0.003)\end{array}$ & $\begin{array}{c}0.019 * * * \\
(0.003)\end{array}$ \\
\hline$R \& D_{i t}$ & $\begin{array}{c}-0.044 * * \\
(0.018)\end{array}$ & $\begin{array}{c}-0.039 * * \\
(0.019)\end{array}$ & $\begin{array}{c}-0.057 * * * \\
(0.018)\end{array}$ & $\begin{array}{c}-0.039 * * \\
(0.019)\end{array}$ & $\begin{array}{c}-0.049 * * \\
(0.019)\end{array}$ & $\begin{array}{c}-0.039 * * \\
(0.018)\end{array}$ \\
\hline TURNOVER $_{i t}$ & $\begin{array}{c}0.021 * * * \\
(0.006)\end{array}$ & $\begin{array}{c}0.065^{* * *} \\
(0.009)\end{array}$ & $\begin{array}{c}0.026 * * * \\
(0.006)\end{array}$ & $\begin{array}{c}0.015^{* * *} \\
(0.006)\end{array}$ & $\begin{array}{c}0.024 * * * \\
(0.006)\end{array}$ & $\begin{array}{c}0.032 * * * \\
(0.009)\end{array}$ \\
\hline$R I S K_{i t}$ & $\begin{array}{c}-0.218^{* * *} \\
(0.028)\end{array}$ & $\begin{array}{c}-0.224 * * * \\
(0.029)\end{array}$ & $\begin{array}{c}-0.214 * * * \\
(0.028)\end{array}$ & $\begin{array}{c}-0.159 * * * \\
(0.029)\end{array}$ & $\begin{array}{c}-0.293 * * * \\
(0.038)\end{array}$ & $\begin{array}{c}-0.228^{* * *} \\
(0.037)\end{array}$ \\
\hline MEDIAN $_{t}$ & $\begin{array}{c}0.175^{* * *} \\
(0.035)\end{array}$ & $\begin{array}{c}0.195^{* * *} * \\
(0.036)\end{array}$ & $\begin{array}{c}0.227 * * * \\
(0.035) \\
\text { Determina }\end{array}$ & $\begin{array}{c}0.183^{* * *} * \\
(0.035) \\
\text { ts of SOA }\end{array}$ & $\begin{array}{c}0.203 * * * \\
(0.036)\end{array}$ & $\begin{array}{c}0.187 * * * \\
(0.034)\end{array}$ \\
\hline$L_{i t-1} \times D I S T A N C E$ & $\begin{array}{c}-0.728^{* * *} \\
(0.071)\end{array}$ & & & & & $\begin{array}{c}-0.609 * * * \\
(0.070)\end{array}$ \\
\hline$L_{i t-1} \times T U R N O V E R_{i t}$ & & $\begin{array}{c}-0.083 * * * \\
(0.014)\end{array}$ & & & & $\begin{array}{c}-0.031 * * \\
(0.015)\end{array}$ \\
\hline$L_{i t-1} \times S I Z E_{i t}$ & & & $\begin{array}{c}-0.027^{* * *} \\
(0.004)\end{array}$ & & & $\begin{array}{c}-0.017 * * * \\
(0.004)\end{array}$ \\
\hline$L_{i t-1} \times G R O W T H_{i t}$ & & & & $\begin{array}{c}-0.401 * * * \\
(0.041)\end{array}$ & & $\begin{array}{c}-0.328^{* * *} \\
(0.039)\end{array}$ \\
\hline$L_{i t-1} \times R I S K_{i t}$ & & & & & $\begin{array}{c}0.641^{* * *} \\
(0.207)\end{array}$ & $\begin{array}{c}0.393 * * * \\
(0.199)\end{array}$ \\
\hline
\end{tabular}

Note: $\quad$ Standard errors in parentheses. *, **, and *** indicate significance at the 10, 5, and 1 percent, respectively. Variable definitions are listed in Table 2. The DPF estimator uses a Gauss-Hermite quadrature to approximate the integrals in the log likelihood function. 
Table 14. DPF Estimates of the dynamic partial adjustment model (excluding services): the heterogeneous case

\begin{tabular}{|c|c|c|c|c|c|c|}
\hline & 1 & 2 & 3 & 4 & 5 & 6 \\
\hline & \multicolumn{6}{|c|}{ Determinants of capital structure } \\
\hline$L_{i t-1}$ & $\begin{array}{c}0.861^{* * *} \\
(0.015)\end{array}$ & $\begin{array}{c}0.905^{* * *} \\
(0.017)\end{array}$ & $\begin{array}{c}0.832^{* * * *} \\
(0.021)\end{array}$ & $\begin{array}{c}0.870^{* * * *} \\
(0.024)\end{array}$ & $\begin{array}{c}0.766^{* * * *} \\
(0.018)\end{array}$ & $\begin{array}{c}0.917 * * * \\
(0.039)\end{array}$ \\
\hline $\mathrm{GROWTH}_{i t}$ & $\begin{array}{c}0.104 * * * \\
(0.009)\end{array}$ & $\begin{array}{c}0.093 * * * \\
(0.009)\end{array}$ & $\begin{array}{c}0.218^{* * * *} \\
(0.018)\end{array}$ & $\begin{array}{c}0.067 * * * \\
(0.009)\end{array}$ & $\begin{array}{c}0.069 * * * \\
(0.009)\end{array}$ & $\begin{array}{c}0.196 * * * \\
(0.017)\end{array}$ \\
\hline$R O A_{i t}$ & $\begin{array}{c}-0.454^{* * * *} \\
(0.025)\end{array}$ & $\begin{array}{c}-0.442 * * * \\
(0.025)\end{array}$ & $\begin{array}{c}-0.419 * * * \\
(0.024)\end{array}$ & $\begin{array}{c}-0.426^{* * * *} \\
(0.025)\end{array}$ & $\begin{array}{c}-0.403^{* * * *} \\
(0.025)\end{array}$ & $\begin{array}{c}-0.416^{* * * *} \\
(0.024)\end{array}$ \\
\hline$S I Z E_{i t}$ & $\begin{array}{c}0.007 * * * \\
(0.003)\end{array}$ & $\begin{array}{c}0.009 * * * \\
(0.003)\end{array}$ & $\begin{array}{c}0.013 * * * \\
(0.003)\end{array}$ & $\begin{array}{c}0.022 * * * \\
(0.003)\end{array}$ & $\begin{array}{c}0.014 * * * \\
(0.003)\end{array}$ & $\begin{array}{c}0.018 * * * \\
(0.003)\end{array}$ \\
\hline$R \& D_{i t}$ & $\begin{array}{c}-0.049 * * \\
(0.019)\end{array}$ & $\begin{array}{c}-0.042 * * \\
(0.018)\end{array}$ & $\begin{array}{l}-0.033^{*} \\
(0.018)\end{array}$ & $\begin{array}{c}-0.050 * * * \\
(0.019)\end{array}$ & $\begin{array}{c}-0.045^{* *} \\
(0.019)\end{array}$ & $\begin{array}{l}-0.030 * \\
(0.018)\end{array}$ \\
\hline TURNOVER $_{i t}$ & $\begin{array}{c}0.014 * * \\
(0.006)\end{array}$ & $\begin{array}{c}0.057 * * * \\
(0.009)\end{array}$ & $\begin{array}{c}0.030 * * * \\
(0.009)\end{array}$ & $\begin{array}{c}0.033 * * * \\
(0.009)\end{array}$ & $\begin{array}{c}0.029 * * * \\
(0.009)\end{array}$ & $\begin{array}{c}0.051 * * * \\
(0.013)\end{array}$ \\
\hline$R_{S I S} K_{i t}$ & $\begin{array}{c}-0.141 * * * \\
(0.040)\end{array}$ & $\begin{array}{c}-0.152 * * * \\
(0.040)\end{array}$ & $\begin{array}{c}-0.131 * * * \\
(0.029)\end{array}$ & $\begin{array}{c}-0.180 * * * \\
(0.029)\end{array}$ & $\begin{array}{c}-0.287 * * * \\
(0.039)\end{array}$ & $\begin{array}{c}-0.229 * * * \\
(0.038)\end{array}$ \\
\hline \multirow[t]{2}{*}{ MEDIAN $_{t}$} & $\begin{array}{c}0.164 * * * \\
(0.037)\end{array}$ & $\begin{array}{c}0.171 * * * \\
(0.041)\end{array}$ & $\begin{array}{c}0.120 * * * \\
(0.041)\end{array}$ & $\begin{array}{c}0.171 * * * \\
(0.041)\end{array}$ & $\begin{array}{c}0.154 * * * \\
(0.041)\end{array}$ & $\begin{array}{c}0.123 * * * \\
(0.039)\end{array}$ \\
\hline & \multicolumn{6}{|c|}{ Determinants of SOA } \\
\hline$L_{i t-1} \times D I S T A N C E$ & $\begin{array}{c}-0.439 * * * \\
(0.080)\end{array}$ & & & & & $\begin{array}{c}-0.412 * * * \\
(0.079)\end{array}$ \\
\hline$L_{i t-1} \times T U R N O V E R_{i t}$ & & $\begin{array}{c}-0.082 * * * \\
(0.014)\end{array}$ & & & & $\begin{array}{c}-0.053 * * \\
(0.023)\end{array}$ \\
\hline$L_{i t-1} \times S I Z E_{i t}$ & & & $\begin{array}{c}-0.020 * * * \\
(0.004)\end{array}$ & & & $\begin{array}{l}-0.11 * * \\
(0.004)\end{array}$ \\
\hline$L_{i t-1} \times G R O W T H_{i t}$ & & & & $\begin{array}{c}-0.438 * * * \\
(0.045)\end{array}$ & & $\begin{array}{c}-0.360 * * * \\
(0.045)\end{array}$ \\
\hline$L_{i t-1} \times R I S K_{i t}$ & & & & & $\begin{array}{c}0.872 * * * \\
(0.210)\end{array}$ & $\begin{array}{c}0.628 * * * \\
(0.204)\end{array}$ \\
\hline
\end{tabular}

Note: $\quad$ Standard errors in parentheses. *,**, and *** indicate significance at the 10, 5, and 1 percent, respectively. Variable definitions are listed in Table 2. The DPF estimator uses a Gauss-Hermite quadrature to approximate the integrals in the log likelihood function. 
Table 15. DPF Estimates of the dynamic partial adjustment model (excluding semiconductors): the heterogeneous case

\begin{tabular}{|c|c|c|c|c|c|c|}
\hline & 1 & 2 & 3 & 4 & 5 & 6 \\
\hline & \multicolumn{6}{|c|}{ Determinants of capital structure } \\
\hline$L_{i t-1}$ & $\begin{array}{c}0.861 * * * \\
(0.015)\end{array}$ & $\begin{array}{c}0.905 * * * \\
(0.017)\end{array}$ & $\begin{array}{c}0.897 * * * \\
(0.021)\end{array}$ & $\begin{array}{c}0.879 * * * \\
(0.024)\end{array}$ & $\begin{array}{c}0.810 * * * \\
(0.019)\end{array}$ & $\begin{array}{c}0.914 * * * \\
(0.031)\end{array}$ \\
\hline GROWTH $_{i t}$ & $\begin{array}{c}0.104 * * * \\
(0.009)\end{array}$ & $\begin{array}{c}0.093 * * * \\
(0.009)\end{array}$ & $\begin{array}{c}0.091 * * * \\
(0.009)\end{array}$ & $\begin{array}{c}0.235^{* * *} \\
(0.019)\end{array}$ & $\begin{array}{c}0.095 * * * \\
(0.009)\end{array}$ & $\begin{array}{c}0.211^{* * *} \\
(0.018)\end{array}$ \\
\hline$R O A_{i t}$ & $\begin{array}{c}-0.454 * * * \\
(0.025)\end{array}$ & $\begin{array}{c}-0.442 * * * \\
(0.025)\end{array}$ & $\begin{array}{c}-0.436 * * * \\
(0.024)\end{array}$ & $\begin{array}{c}-0.438 * * * \\
(0.025)\end{array}$ & $\begin{array}{c}-0.429 * * * \\
(0.025)\end{array}$ & $\begin{array}{c}-0.439 * * * \\
(0.024)\end{array}$ \\
\hline$S I Z E_{i t}$ & $\begin{array}{c}0.007 * * * \\
(0.003)\end{array}$ & $\begin{array}{c}0.009 * * * \\
(0.003)\end{array}$ & $\begin{array}{c}0.018^{* * *} \\
(0.003)\end{array}$ & $\begin{array}{c}0.006 * * \\
(0.003)\end{array}$ & $\begin{array}{c}0.008^{* * *} \\
(0.003)\end{array}$ & $\begin{array}{c}0.012 * * * \\
(0.003)\end{array}$ \\
\hline$R \& D_{i t}$ & $\begin{array}{c}-0.049 * * \\
(0.019)\end{array}$ & $\begin{array}{c}-0.042 * * \\
(0.018)\end{array}$ & $\begin{array}{c}-0.054 * * * \\
(0.018)\end{array}$ & $\begin{array}{c}-0.040^{* * *} \\
(0.018)\end{array}$ & $\begin{array}{c}-0.051 * * * \\
(0.019)\end{array}$ & $\begin{array}{c}-0.040 * * \\
(0.017)\end{array}$ \\
\hline TURNOVER $_{i t}$ & $\begin{array}{l}0.014 * * \\
(0.006)\end{array}$ & $\begin{array}{c}0.057 * * * \\
(0.009)\end{array}$ & $\begin{array}{c}0.017 * * * \\
(0.006)\end{array}$ & $\begin{array}{c}0.008 * * * \\
(0.006)\end{array}$ & $\begin{array}{c}0.016^{* * *} \\
(0.006)\end{array}$ & $\begin{array}{c}0.031 * * * \\
(0.009)\end{array}$ \\
\hline$R I S K_{i t}$ & $\begin{array}{c}-0.141 * * * \\
(0.040)\end{array}$ & $\begin{array}{c}-0.152 * * * \\
(0.040)\end{array}$ & $\begin{array}{c}-0.131 * * * \\
(0.039)\end{array}$ & $\begin{array}{c}-0.086^{* * *} \\
(0.040)\end{array}$ & $\begin{array}{c}-0.266^{* * *} \\
(0.059)\end{array}$ & $\begin{array}{c}-0.192 * * * \\
(0.059)\end{array}$ \\
\hline MEDIAN $_{t}$ & $\begin{array}{c}0.164 * * * \\
(0.037)\end{array}$ & $\begin{array}{c}0.171^{* * *} \\
(0.041)\end{array}$ & $\begin{array}{c}0.187 * * * \\
(0.036) \\
\text { Determin }\end{array}$ & $\begin{array}{c}0.160 * * * \\
(0.037) \\
\text { nts of SOA }\end{array}$ & $\begin{array}{c}0.179 * * * \\
(0.037)\end{array}$ & $\begin{array}{c}0.171 * * * \\
(0.036)\end{array}$ \\
\hline$L_{i t-1} \times$ DISTANCE & $\begin{array}{c}-0.439 * * * \\
(0.080)\end{array}$ & & & & & $\begin{array}{c}-0.336 * * * \\
(0.079)\end{array}$ \\
\hline$L_{i t-1} \times T U R N O V E R_{i t}$ & & $\begin{array}{c}-0.082^{* * *} \\
(0.014)\end{array}$ & & & & $\begin{array}{c}-0.038 * * \\
(0.015)\end{array}$ \\
\hline$L_{i t-1} \times S I Z E_{i t}$ & & & $\begin{array}{c}-0.019 * * * \\
(0.004)\end{array}$ & & & $\begin{array}{c}-0.009 * * \\
(0.004)\end{array}$ \\
\hline$L_{i t-1} \times G R O W T H_{i t}$ & & & & $\begin{array}{c}-0.362 * * * \\
(0.043)\end{array}$ & & $\begin{array}{c}-0.296 * * * \\
(0.042)\end{array}$ \\
\hline$L_{i t-1} \times R I S K_{i t}$ & & & & & $\begin{array}{c}0.702 * * * \\
(0.244)\end{array}$ & $\begin{array}{c}0.471 * * * \\
(0.240)\end{array}$ \\
\hline
\end{tabular}

Note: $\quad$ Standard errors in parentheses. *, **, and *** indicate significance at the 10, 5, and 1 percent, respectively. Variable definitions are listed in Table 2. The DPF estimator uses a Gauss-Hermite quadrature to approximate the integrals in the log likelihood function. 


\section{APPENDIX:}

Figure 1: Average LEVERAGE by year

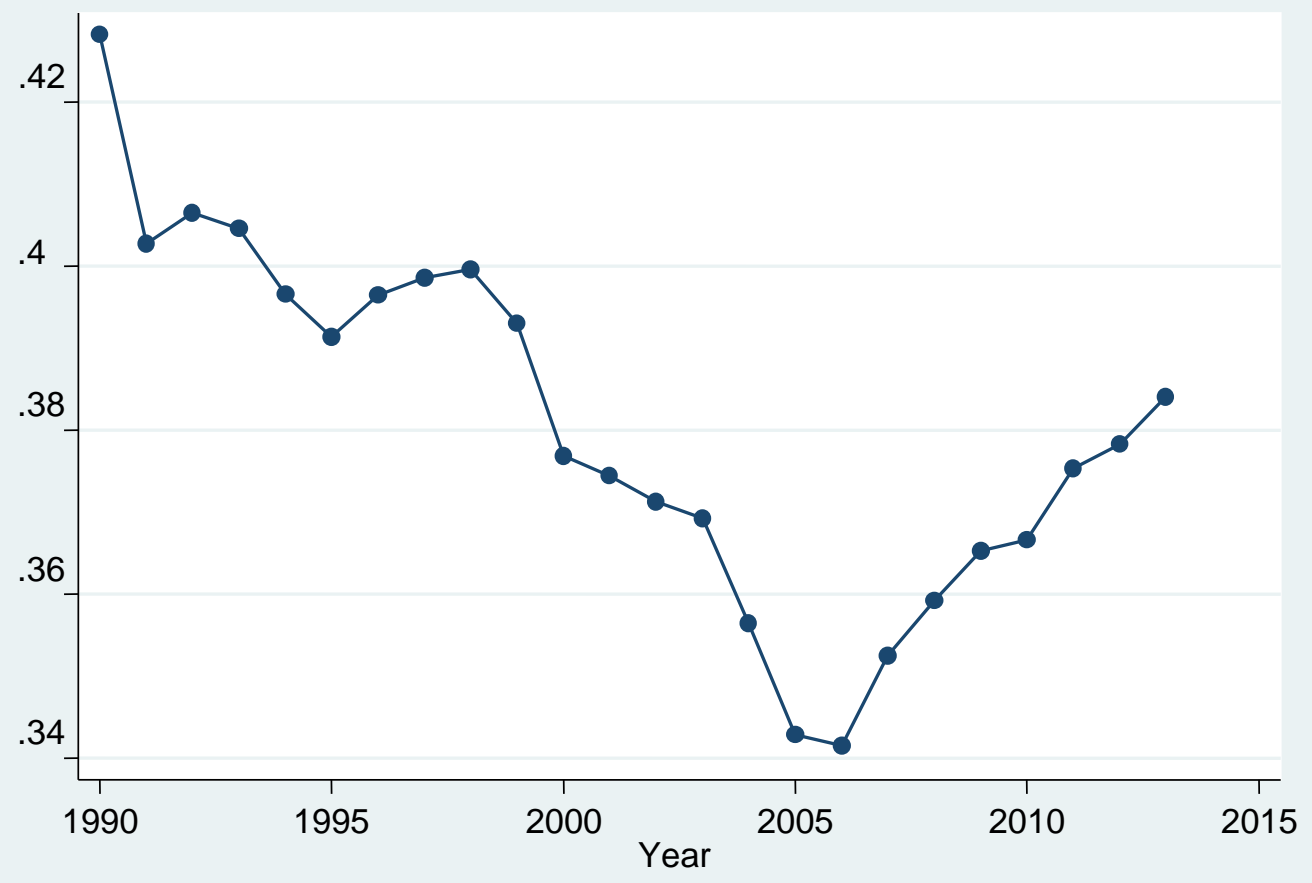


Figure 2: Average ROA by year

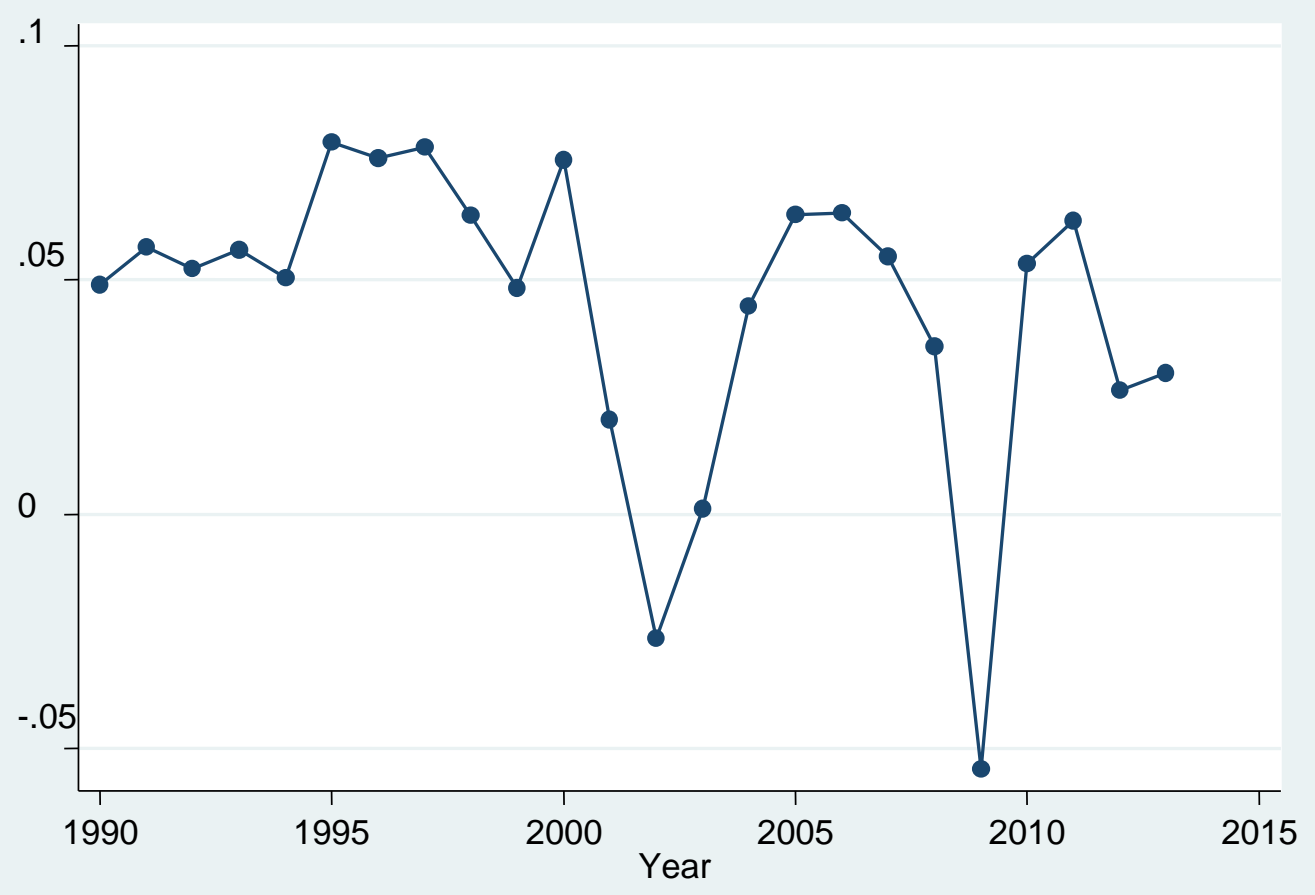

Figure 3: Average R\&D by year

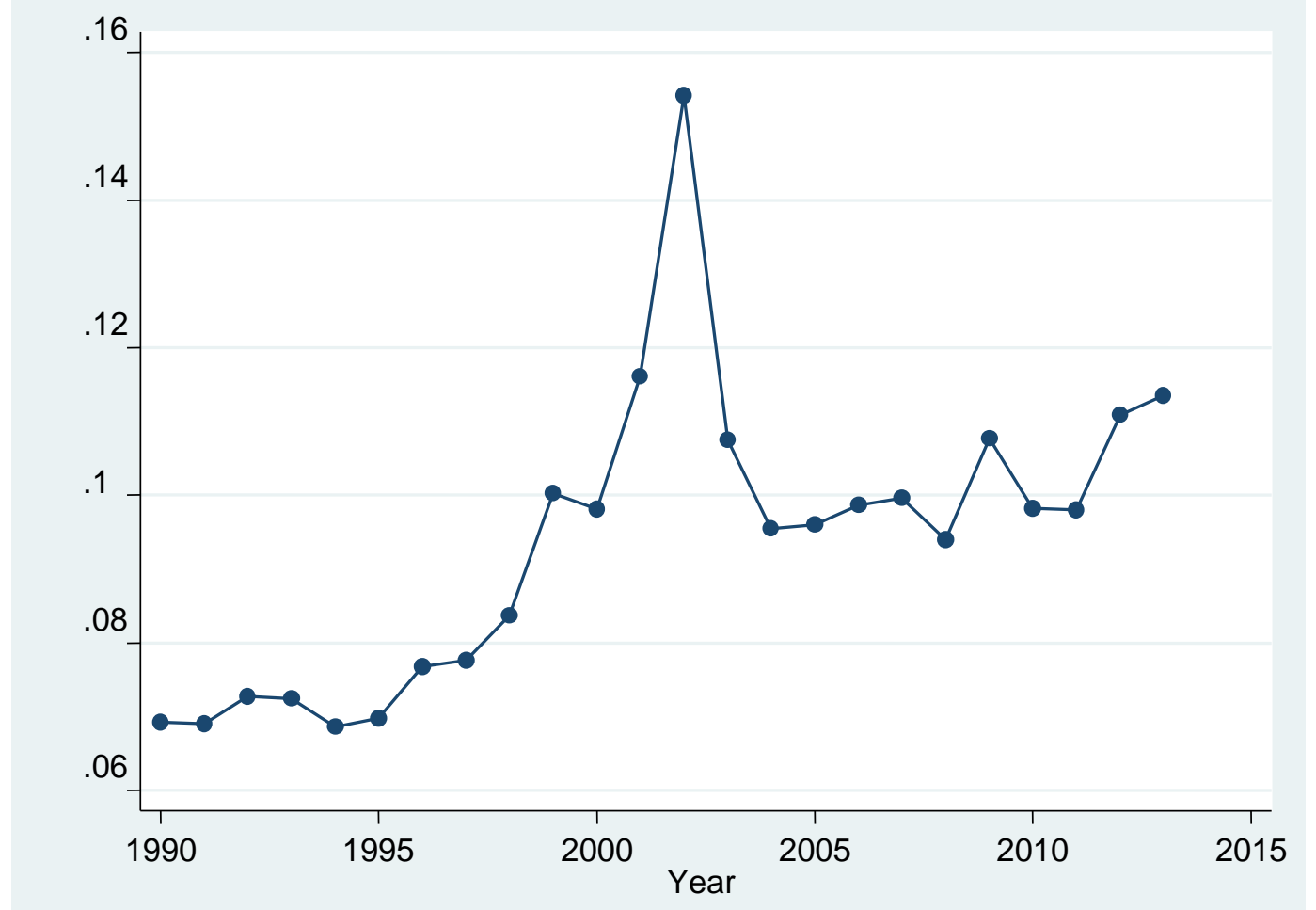


Figure 4: Average firm SIZE by year

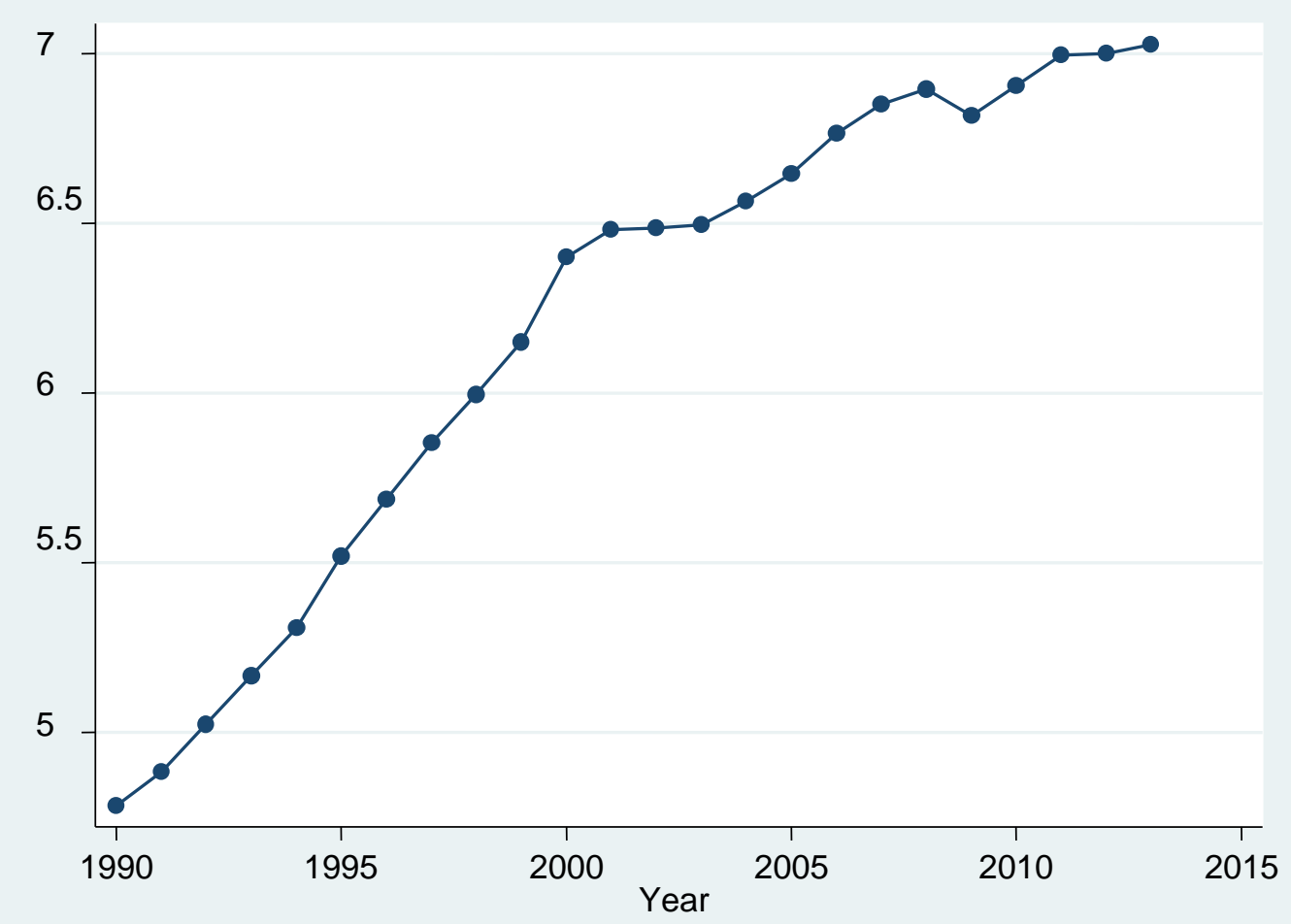

Figure 5: Average GROWTH by year

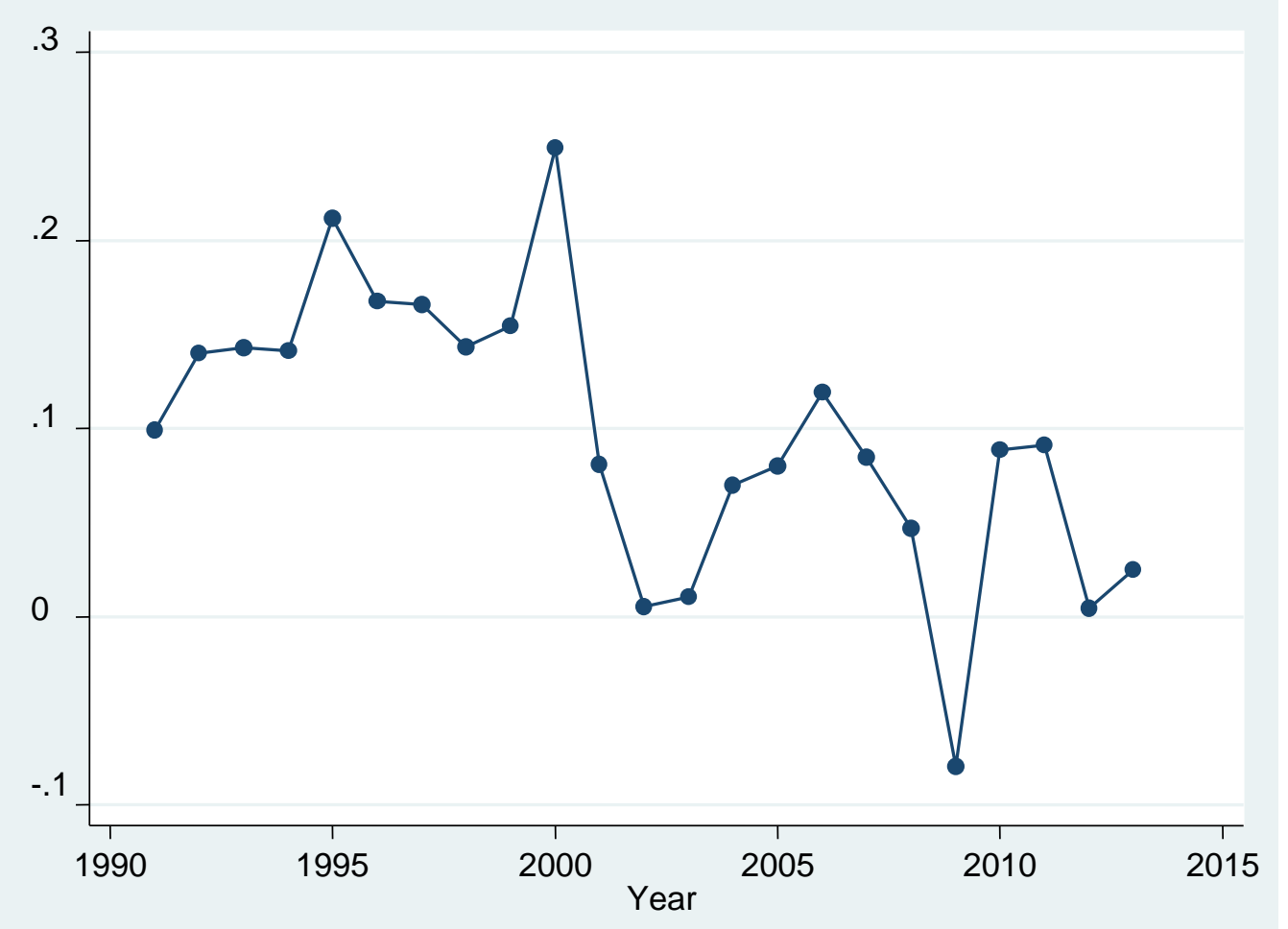


Figure 6: Average default RISK by year

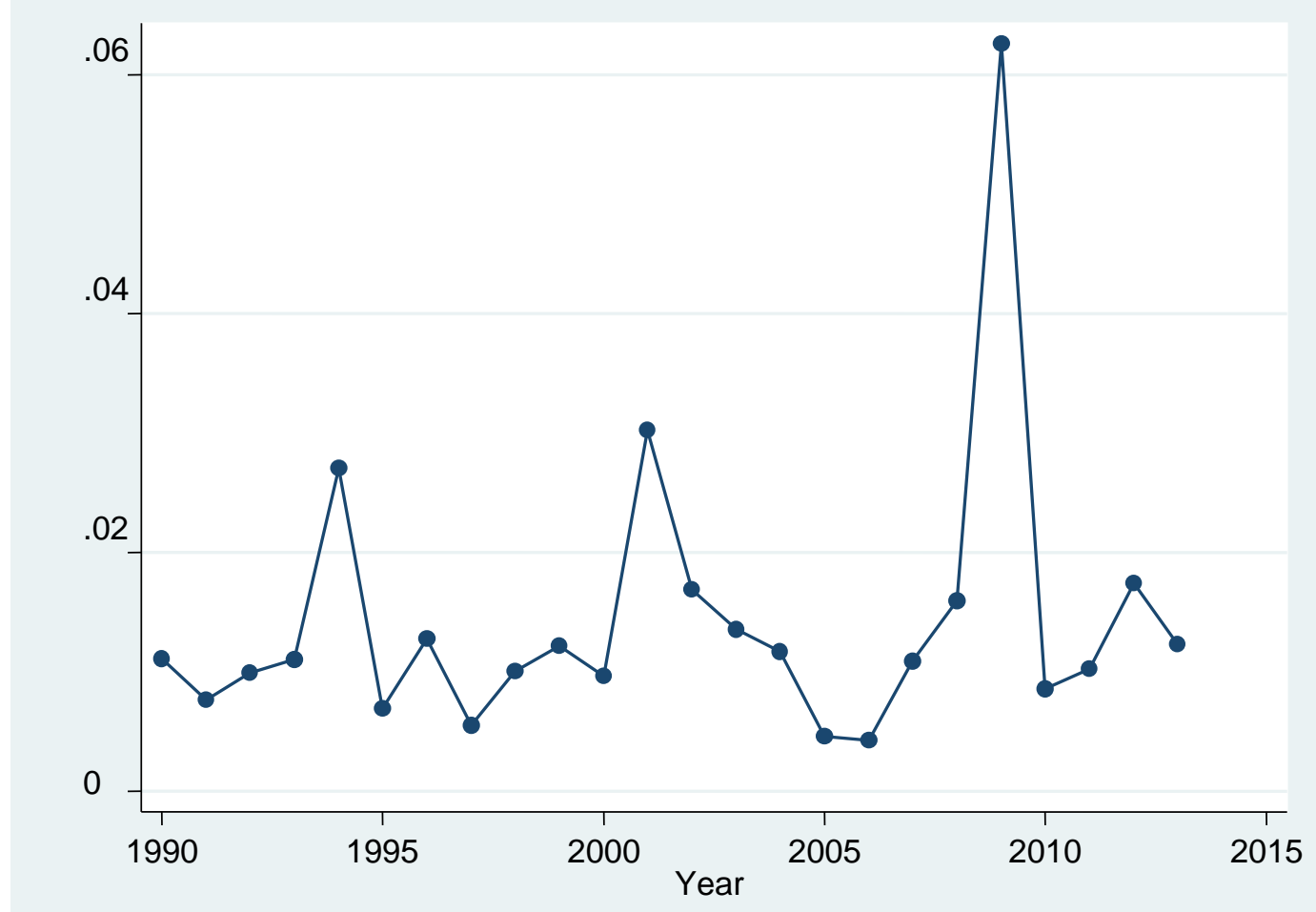

Figure 7: Average Industry MEDIAN by year

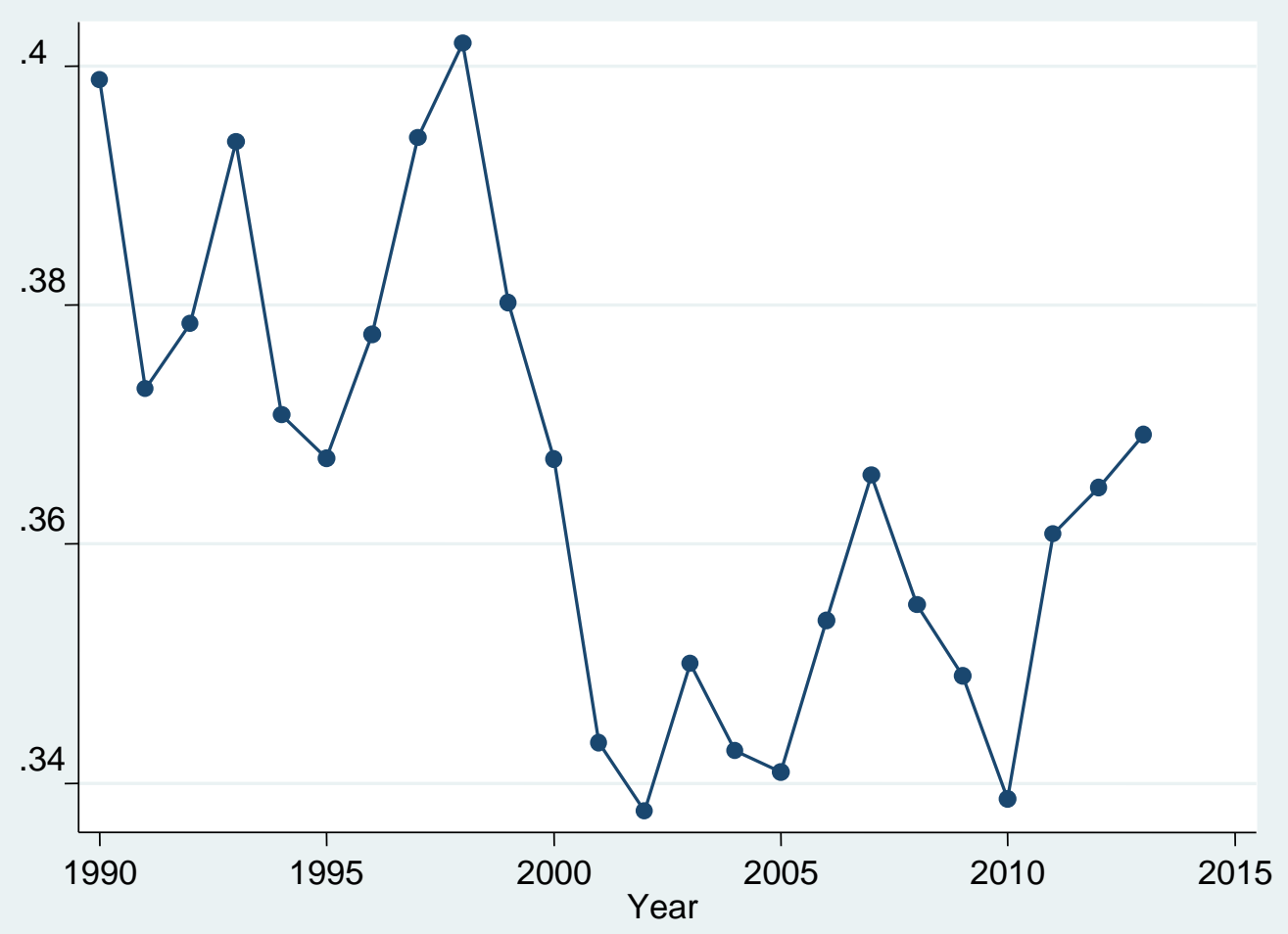




\section{References:}

Aghion, P., Bond, S., Klemm, A., and Marinescu, I. (2004). Technology and financial structure: Are innovative firms different? Journal of the European Economic Association 2(2-3), 277-288.

Ang, J., Cole, R., and Lin, J. (2000). Agency costs and ownership structure. Journal of Finance 55(1), 81-106.

Arellano, M., and Bond, S. (1991). Some tests of specification for panel data: Monte Carlo evidence and an application to employment equations. Review of Economic Studies 58(2), 277-297

Aybar-Arias, C., Casino-Martinez, A., and Lopez-Gracia, J. (2012). On the adjustment speed of SMEs to their optimal capital structure. Small Business Economics 39(4), 977-996.

Bah, R., and Dumontier, P. (2001). R\&D intensity and corporate financial policy: Some international comparisons. Journal of Business Finance and Accounting 28(5-6), 671-692.

Baker, H. K., and Martin, G. S. (2011). Capital Structure and Corporate Financing Decisions: Theory, Evidence, and Practice (vol. 15). John Wiley \& Sons.

Banerjee, S., Heshmati, A., and Wihlborg, C. (2004). The dynamics of capital structure. Research in Banking and Finance 4, 275-297.

Barclay, M. J., and Smith, C. W. (2005). The capital structure puzzle: The evidence revisited. Journal of Applied Corporate Finance 17(1), 8-17.

Berger, A., and Bonaccorsi di Patti, E. (2006). Capital structure and firm performance: A new approach to testing agency theory and an application to the banking industry. Journal of Banking and Finance 30(4), 1065-1102.

Bertschek, I. (2012). ICT, internet and worker productivity. In S. N. Durlauf and L. E. Blume, The New Palgrave Dictionary of Economics. The New Palgrave Dictionary of Economics. Palgrave Macmillan (Online Edition).

Bhargava, A., and Sargan, J. D. (1983). Estimating dynamic random effects models from panel data covering short time periods. Econometrica 51(6), 1635-1659.

Blundell, R., and Bond, S. (2000). GMM estimation with persistent panel data: An application to production functions. Econometric Reviews 19(3), 321-340.

Bradley, M., Jarrell, G., and Kim, E. H. (1984). On the existence of an optimal capital structure: Theory and evidence. Journal of Finance 39(3), 857-878.

Brierley, P. (2001). The financing of technology-based small firms: A review of the literature. Bank of England Quarterly Bulletin 41, 64-83. 
Bruinshoofd, W. A., and de Haan, L. (2005). Financing the new economy: Are ICT firms really that different? Working paper, De Nederlandsche Bank, Amsterdam, The Netherlands.

Bruno, G. S. F. (2005). Approximating the bias of the LSDV estimator for dynamic unbalanced panel data models. Economics Letters 87(3), 361-366.

Cardona, M., Kretschmer, T., and Strobel, T. (2013). ICT and productivity: conclusions from the empirical literature. Information Economics and Policy 25(3), 109-125

Castro, P., Tascon, M. T., and Amor-Tapia, B. (2015). Dynamic analysis of the capital structure in technological firms based on their life cycle stages. Revista Espanola de Financiacion y Contabilidad 44(4), 458-486.

Chang, X., and Dasgupta, S. (2009). Target behavior and financing: How conclusive is the evidence? Journal of Finance 64(4), 1767-1796.

Chang, H., and Song, F. M. (2014). R\&D investment and capital structure. Working Paper. University of Hong Kong.

Chang, Y-K., Chou, R. K., and Huang, T-H. (2014). Corporate governance and the dynamics of capital structure: New evidence, Journal of Banking and Finance 48, 374-385.

Chen, L., and Zhao, X. (2007). Mechanical mean reversion of leverage ratios. Economics Letters 95(2), 223-229.

Cook, D., and Tang, T. (2010). Macroeconomic conditions and capital structure adjustment speed. Journal of Corporate Finance 16(1), 73-87.

Cortez, M. A., and Susanto, S. (2012). The determinants of corporate capital structure: Evidence from Japanese manufacturing companies. Journal of International Business Research 10(3), 121-134.

Dang, V. A., Kim, M., and Shin, Y., (2012). Asymmetric capital structure adjustments: New evidence from dynamic panel threshold models. Journal of Empirical Finance 19(4), 465482.

De Miguel, A., and Pintado, J. (2001). Determinants of capital structure: New evidence from Spanish panel data. Journal of Corporate Finance 7(1), 77-99.

Degryse, H., de Goeij, P., and Kappert, P. (2012). The impact of firm and industry characteristics on small firms' capital structure. Small Business Economics 38(4), 431- 447.

De Vos, I., Everaert, G., and Ruyssen, I. (2015). Bootstrap-based bias correction and inference for dynamic panels with fixed effects. Stata Journal 15(4), 986-1018. 
Drobetz, W., and Wanzenried, G. (2006). What determines the speed of adjustment to the target capital structure? Applied Financial Economics 16(13), 941-958.

Elsas, R., and Florysiak, D. (2011). Heterogeneity in the speed of adjustment toward target leverage. International Review of Finance 11(2), 181-211.

Elsas, R., and Florysiak, D. (2015). Dynamic capital structure adjustment and the impact of fractional dependent variables. Journal of Financial and Quantitative Analysis 50(5), 11051133.

Everaert, G., and L. Pozzi. (2007). Bootstrap-based bias correction for dynamic panels. Journal of Economic Dynamics and Control 31(4), 1160-1184.

Fama, E. F., and French, K. R. (2002). Testing trade- off and pecking order predictions about dividends and debt. Review of financial studies 15(1), 1-33.

Faulkender, M., and Petersen, M. A. (2006). Does the source of capital affect capital structure? Review of financial studies 19(1), 45-79.

Faulkender, M. W., Flannery, M. J., Hankins, K. W., and Smith, J. M. (2012). Cash flows and leverage adjustments. Journal of Financial Economics 103(3), 632-646.

Fischer, E., Heinkel, R. and Zechner, J. (1989). Dynamic capital structure choice: Theory and tests. Journal of Finance 44(1), 19-40.

Flannery, M. J., and Hankins, K. W. (2013). Estimating dynamic panel models in corporate finance. Journal of Corporate Finance 19, 1-19.

Flannery, M. J., and Rangan, K. P. (2006), Partial adjustment toward target capital structures. Journal of Financial Economics 79(3), 469-506.

Frank, M. Z., and Goyal, V. K. (2009). Capital structure decisions: Which factors are reliably important? Financial Management 38(1), 1-37.

Garvey, G. T., and Mawani, A. (2007). Executive stock options and dynamic risk-taking incentives. Managerial Finance 33(4), 281-288.

Getzmann, A., Lang, S., and Spremann, K. (2014). Target capital structure and adjustment speed in Asia. Asia- Pacific Journal of Financial Studies 43(1), 1-30.

González, V., and González, F. (2012). Firm size and capital structure: Evidence using dynamic panel data. Applied Economics 44(36), 4745-4754.

Graham, J., and Harvey, C. (2001). The theory and practice of corporate finance: Evidence from the field. Journal of Financial Economics 60(2-3), 187-243. 
Hansen, L. P. (1982). Large sample properties of generalized method of moments estimators. Econometrica 50(4), 1029-1054.

Hahn J., Hausman J., and Kuersteiner, G. (2007). Long difference instrumental variables estimation for dynamic panel models with fixed effects. Journal of Econometrics 140(2), 574-617.

Hanousek, J., and Shamshur, A. (2011). A stubborn persistence: Is the stability of leverage ratios determined by the stability of the economy? Journal of corporate finance 17(5), 1360-1376.

Harris, M., and Raviv, A. (1991). The theory of capital structure. Journal of Finance 46(1), 297355.

Hausman, J. A. (1978). Specification tests in econometrics. Econometrica 46(6), 1251-1271.

Heshmati, A. (2002). The dynamics of capital structure: Evidence from Swedish micro and small firms, in Hasan, I. and Hunter, W. (eds.) Research in Banking and Finance, Vol. 2, Elsevier Sciences, Amsterdam.

Hogan, T., and Hutson, E. (2005). Capital structure in new technology-based firms: Evidence from the Irish software sector. Global Finance Journal 15(3), 369-387.

Hovakimian, A., and Li, G. H. (2012). Is the partial adjustment model a useful tool for capital structure research? Review of Finance 16(3), 733-754.

Hsiao, C., Pesaran, M. H., and Tahmiscioglu, A. K. (2002). Maximum likelihood estimation of fixed effects dynamic panel data models covering short time periods. Journal of Econometrics 109(1), 107-150.

Huang, R., and Ritter, J. R. (2009). Testing theories of capital structure and estimating the speed of adjustment. Journal of Financial and Quantitative Analysis 44(2), 237-271.

Hyytinen, A., and Pajarinen, M. (2005). Financing of technology-intensive small businesses: Some evidence on the uniqueness of the ICT sector. Information Economics and Policy 17(1), 115132.

Iliev, P., and Welch, I. (2010). Reconciling estimates of the speed of adjustment of leverage ratios. Available at SSRN: http://ssrn.com/abstract= 1542691.

Jensen, M. C. (1986). Agency costs of free cash flow, corporate finance and takeovers. American Economic Review 76(2), 323-329.

Jensen, M. C., and Meckling, W. (1976). Theory of the firm, managerial behavior, agency costs and ownership structure. Journal of Financial Economics 3(4), 305-360.

Jorgenson, D. W., and Stiroh, K. J. (1999). Information technology and growth. American Economic Review 89(2), 109-115. 
Jorgenson, D. W., and Timmer, M. P. (2011). Structural change in advanced nations: A new set of stylized facts. Scandinavian Economic Journal 113(1), 1-29.

Kayhan, A., and Titman, S. (2007). Firms' histories and their capital structures. Journal of Financial Economics 83(1), 1-32

Kim, H., Heshmati, A., and Aoun, D. (2006). Dynamics of capital structure: The case of Korean listed manufacturing companies. Asian Economic Journal 20(3), 275-302.

Kiviet, J. F. (1995). On bias, inconsistency and efficiency of various estimators in dynamic panel data models. Journal of Econometrics 68(1), 53-78.

Korajczyk, R. A., and Levy, A. (2003). Capital structure choice: macroeconomic conditions and financial constraints, Journal of Financial Economics 68(1), 75-109.

Kripfganz, S. (2016). Quasi-maximum likelihood estimation of linear dynamic short-T panel-data models. Stata Journal 16(4), 1013-1038.

Leary, M. T., and Roberts, M. R. (2005). Do firms rebalance their capital structures? The Journal of Finance 60(6), 2575-2619.

Leland, H. (1994). Corporate debt value, bond covenants, and optimal capital structure. Journal of Finance 49(4), 1213-1252.

Lemmon, M. L., Roberts, M. R., and Zender, J. F. (2008). Back to the beginning: persistence and the cross-section of corporate capital structure. Journal of Finance 63(4), 1575-1608.

Liao, L., Mukherjee, T., and Wang, W. (2015). Corporate governance and capital structure dynamics: An empirical study. Journal of Financial Research 38(2), 169-191.

Liu, Q. (2001). Growth opportunities, knowledge capital, and leverage: Evidence from US biotech firms. Working Paper, University of Hong Kong. Available at: https://ssrn.com/abstract $=248908$

Lööf, H. (2003). Dynamic optimal capital structure and technological change. ZEW Discussion Paper No. 03-06. Available at SSRN: https://ssrn.com/abstract=421460

López-Gracia, J., and Sogorb-Mira, F. (2008). Testing trade-off and pecking order theories financing SMEs. Small Business Economics 31(2), 117-136.

Loudermilk, M. E. (2007). Estimation of fractional dependent variables in dynamic panel data models with an application to firm dividend policy. Journal of Business and Economic Statistics 25(4), 462-472. 
MacKay, P., and Phillips, G. M. (2005). How does industry affect firm financial structure? Review of Financial Studies 18(4), 1433-1466.

Modigliani, F., and Miller, M. (1958). The cost of capital, corporation finance, and the theory of investment. American Economic Review 48(3), 261-297.

Moral-Benito, E. (2013). Likelihood-based estimation of dynamic panels with predetermined regressors. Journal of Business and Economic Statistics 31(4), 451-472.

Morellec, E., Nikolov, B., and Schurhoff, N. (2012). Corporate governance and capital structure dynamics. Journal of Finance 67(3), 801-847.

Moyo, V. (2016). Dynamic capital structure adjustment: Which estimator yields consistent and efficient estimates? Journal of Economic and Financial Sciences 9(1), 209-227.

Mukherjee, S., and Mahakud, J. (2012). Are trade-off and pecking order theories of capital structure mutually exclusive? Evidence from Indian manufacturing firms. Journal of Management Research 12(1), 41-55.

Myers, S. C. (1977). Determinants of corporate borrowing. Journal of Financial Economics 5(2), 147-175.

Myers, S. C. (1984). The capital structure puzzle. Journal of Finance 39(3), 575-592.

Myers, S. C. (2001). Capital structures. Journal of Economic Perspectives. 15(2), 81-102.

Myers, S. C., and Majluf, N. S. (1984). Corporate financing and investment decisions when firms have information that investors do not have. Journal of Financial Economics 13(2), 187-221.

National Science Foundation, National Center for Science and Engineering Statistics, and U.S. Census Bureau. Business R\&D and Innovation Survey, 2013.

National Science Foundation, National Center for Science and Engineering Statistics, and U.S. Census Bureau. Business R\&D and Innovation Survey, 2016.

Nickell, S. (1981). Biases in dynamic models with fixed effects. Econometrica 49(6), 1417-1426.

Ozkan, A. (2001). Determinants of capital structure and adjustment to long run target: Evidence from UK company panel data. Journal of Business Finance and Accounting 28(1-2), 175198.

Oztekin, O., and Flannery, M. J. (2012). Institutional determinants of capital structure adjustment speeds. Journal of Financial Economics 103(1), 88-112.

Rajan, R. G., and Zingales, L. (1995). What do we know about capital structure? Some evidence from international data. Journal of Finance 50(5), 1421-1460. 
Rashid, A. (2016). Does risk affect capital structure adjustments? Journal of Risk Finance 17(1), 80-92.

Roodman, D. (2009). How to do xtabond2? An introduction to difference and system GMM in Stata. Stata Journal 9(1), 86-136.

Shyam-Sunder, L., and Myers, C. S. (1999). Testing static tradeoff against pecking order models of capital structure. Journal of Financial Economics 51(2), 219-244.

Simerly, R., and Li, M. (2000). Environmental dynamism, capital structure and performance: A theoretical integration and an empirical test. Strategic Management Journal 21(1), 31-49.

Singh, M., and Faircloth, S. (2005). The impact of corporate debt on long term investment and firm performance. Applied Economics 37(8), 875-883.

Strebulaev, I. (2007). Do tests of capital structure theory mean what they say? Journal of Finance 62(4), 1747-1787.

Titman, S. (1984). The effect of capital structure on a firm's liquidation decision. Journal of Financial Economics 13(1), 137-151.

Titman, S., and Wessels, R. (1988). The determinants of capital structure. Journal of Finance 43(1), $1-19$.

Tobin, J. (1958). Estimation of relationships for limited dependent variables. Econometrica 26(1), 24-36.

Vicente-Lorente, J. D. (2001). Specificity and opacity as resource-based determinants of capital structure: Evidence for Spanish manufacturing firms. Strategic Management Journal 22(2), 157-177.

Welch, I. (2004). Capital structure and stock returns. Journal of Political Economy 112(1), 106-131.

Wooldridge, J. M. (2005). Unobserved heterogeneity and estimation of average partial effects, in Identification and Inference for Econometric Models: Essays in Honor of Thomas Rothenberg, ed. D. W. K. Andrews and J. H. Stock. Cambridge: Cambridge University Press, 27-55.

Wooldridge, J. M. (2010). Correlated random effects models with unbalanced panels. Manuscript, Department of Economics, University of Michigan.

Windmeijer, F. (2005). A finite sample correction for the variance of linear efficient two-step GMM estimators. Journal of Econometrics 126(1), 25-51. 